\title{
O przypadkach dokonanej transkrypcji aktów urodzenia dzieci par jednopłciowych
}

\begin{abstract}
The article concerns the problem of birth certificates of children of same sex couples, which have been transcribed into the Polish register of civil status. Although such transcriptions, after the resolution of the Supreme Administrative Court of 2.12.2019, seem not to be allowed, a significant number of foreign certificates had already been transcribed beforehand. The author argues that there are limited grounds to eliminate such acts from the Polish register. Especially in cases, in which the transcribed birth act - generated in Poland - names the woman who gave birth to the child (which woman is always considered to be the mother according to Polish law), such acts can properly fulfill their role by proving the fact of the child's birth and by explaining the motherhood. The fact that the other parent (of the same sex) is not mentioned at all or is mentioned only in an annotation to a birth act can be well reconciled with the rules of the Polish law.
\end{abstract}

Keywords: Transcription of civil status certificates - registration of civil status - annulment of a civil status act — same sex couples — parenthood of same sex persons

a) Dr hab., prof. UŁ, Uniwersytet Łódzki. 


\section{Wprowadzenie}

Zgodnie z art. 104 ust. 2 ustawy z 28 listopada 2014 r. - Prawo o aktach stanu cywilnego ${ }^{1}$, „Zagraniczny dokument stanu cywilnego, będący dowodem zdarzenia i jego rejestracji, może zostać przeniesiony do rejestru stanu cywilnego w drodze transkrypcji”. Powołany przepis stanowi podstawę przepisania do polskiego rejestru (inaczej umiejscowienia) aktów stanu cywilnego sporządzonych w innych państwach. Choć regulacja ustawowa nie przewiduje przesłanki istnienia obiektywnego związku zagranicznego aktu z Polską (potencjalnie przenieść można każdy akt potwierdzający urodzenie, małżeństwo lub zgon dowolnej osoby fizycznej sporządzony w jakimkolwiek państwie na świecie), w praktyce wnioski o transkrypcję najczęściej składają osoby, które posiadają już akty stanu cywilnego w polskim rejestrze, a także obywatele polscy, których dzieci rodzą się za granicą. Powodem takiego stanu rzeczy jest art. 104 ust. 5 p.a.s.c., który stanowi: „Transkrypcja jest obligatoryjna, jeżeli obywatel polski, którego dotyczy zagraniczny dokument stanu cywilnego, posiada akt stanu cywilnego potwierdzający zdarzenia wcześniejsze sporządzony na terytorium Rzeczypospolitej Polskiej i żąda dokonania czynności z zakresu rejestracji stanu cywilnego lub ubiega się o polski dokument tożsamości, lub nadanie numeru PESEL".

W ostatnich latach, w kontekście przepisów o transkrypcji, coraz częściej pojawia się pytanie o możliwość odnotowania w Polsce, w tym właśnie trybie, urodzenia dzieci, których (prawne) rodzicielstwo przypisano za granicą osobom tej samej płci. W licznych państwach, w Europie i na świecie, spotykamy dziś bowiem instytucjonalne związki par jednopłciowych (małżeństwa homoseksualne lub związki partnerskie). Przepisy obowiązujące w tych państwach pozwalają zazwyczaj, aby takim parom przypisać rodzicielstwo dziecka. Jak wiadomo, prawo polskie nie zna podobnych konstrukcji. Trzeba mieć jednak świadomość, że coraz większa grupa polskich obywateli (zazwyczaj stale mieszkających za granicą) zawiera w innych państwach związki jednopłciowe i rejestruje urodzenie dzieci, występując $\mathrm{w}$ roli rodziców. Powoduje to oczywiste napięcia w kontekście rejestracji stanu cywilnego², ilekroć zainteresowani chcą skorzystać z możliwości wprowadzania zagranicznych dokumentów (aktów związków jednopłciowych i aktów urodzenia dzieci z takich

1 T.j. Dz.U. 2020, poz. 463 [dalej: p.a.s.c.].

${ }_{2}$ Zob. na ten temat M. Wojewoda, Wspótczesne modele prawa rodzinnego a rejestracja stanu cywilnego, „Metryka” 2019, nr 2, s. 61 i n.; M. Wojewoda, Jeszcze o uznawaniu stanu cywilnego w stosunkach transgranicznych, „Metryka” 2020, nr 1, s. 87 i n. 
związków) do polskiego rejestru. Pojawia się bowiem pytanie o możliwość oraz sposób odnotowania w Polsce konstrukcji nieznanych prawu polskiemu.

Odpowiedzi należy poszukiwać indywidualnie dla poszczególnych grup przypadków ${ }^{3}$. Przedmiotem naszych rozważań będą wyłącznie zagadnienia dotyczące transkrypcji aktów urodzenia dzieci par jednopłciowych. Szczególną uwage przyciąga najczęstszy w praktyce przypadek, kiedy to rodzicielstwo zostaje za granicą przypisane dwóm kobietom, przy czym matką rodzącą dziecko jest obywatelka Polski. Tę grupę sytuacji wyróżnia okoliczność, że dziecko, z mocy samego prawa, uzyskuje polskie obywatelstwo. Jak bowiem stanowi art. 14 pkt 1 ustawy z 2 kwietnia 2009 r. o obywatelstwie polskim ${ }^{4}$, „Małoletni nabywa obywatelstwo polskie przez urodzenie, w przypadku gdy co najmniej jedno z rodziców jest obywatelem polskim”. W świetle zaś obowiązujących w Polsce przepisów Kodeksu rodzinnego i opiekuńczego ${ }^{5}$ (zob. art. $61^{9}$ k.r.o.) relacja rodzicielska z kobietą, która dziecko urodziła, nie może budzić wątpliwości ${ }^{6}$.

${ }^{3}$ Jeśli chodzi o odnotowywanie w Polsce instytucjonalnych związków nieznanych prawu polskiemu zob. M. Wojewoda, Matżeństwa jednoptciowe $i$ zwiazki partnerskie w polskim rejestrze stanu cywilnego?, „Studia Prawno-Ekonomiczne” 2017, T. 103, s. 133 i n.; por. E. Kamarad, Zaświadczenie o stanie cywilnym a matżeństwa i zwiazki partnerskie osób tej samej ptci, „Problemy Prawa Prywatnego Międzynarodowego” 2017, T. 17 , s. 75 .

${ }^{4}$ T.j. Dz.U. 2020, poz. 347.

${ }^{5}$ Ustawa z 25.02.1964 r. — Kodeks rodzinny i opiekuńczy, t.j. Dz.U. 2020, poz. 1359 [dalej: k.r.o.].

${ }^{6}$ Podobnej oczywistości nie ma, gdy polskie obywatelstwo ma wynikać z pochodzenia dziecka od mężczyzny będącego obywatelem Polski. O tym, że dany mężczyzna jest rodzicem w rozumieniu art. 14 ustawy o obywatelstwie polskim decydować powinny, jak się zdaje, przepisy polskiego prawa rodzinnego. Po pierwsze dlatego, że chodzi o pojęcie wynikające z polskiej ustawy publicznoprawnej, w której trudno oczekiwać odwołań do rodzicielstwa według prawa obcego. Po wtóre zaś, art. 55 ustawy z 4.02 .2011 r. - Prawo prywatne międzynarodowe (t.j. Dz.U. 2015, poz. 1792 [dalej: p.p.m.]) wskazuje, że w przypadku polskiego obywatelstwa dziecka dla ustalenia jego pochodzenia właściwe jest prawo polskie, por. M. Pilich, Uznanie dziecka a problematyka obywatelstwa, „Metryka" 2017, nr 1, s. 35-37. Tymczasem, według polskiego Kodeksu rodzinnego i opiekuńczego, ojcostwo jest zawsze pochodną macierzyństwa określonej kobiety (zob. art. 62, art. 73 oraz art. 85 k.r.o.). Dlatego też dla przesądzenia ojcostwa danego mężczyzny nie wystarczy odpis zagranicznego aktu urodzenia, w którym jako rodziców podano dwóch mężczyzn, czy też akt urodzenia, w którym wskazano wyłącznie ojca, bo dziecko urodziła matka zastępcza niepodlegająca ujawnieniu w akcie. Sama więź genetyczna nie jest według prawa polskiego samoistną podstawą ustalenia pochodzenia dziecka. Z powyższych względów pewne zastrzeżenia mogą budzić wyroki NSA z 29.08.2018 r., II OSK 2129/16, oraz z 10.09.2020 r., II OSK 3362/17, w których, bez głębszego uzasadnienia, za wystarczający dowód ojcostwa obywatela Polski przyjęto zagraniczne dokumenty, z których w ogóle nie wynikało macierzyństwo. 
Polskie obywatelstwo dziecka prowadzi do oczywistego, jak się zdaje, wniosku, że osobie takiej nie można odmówić wydania polskiego dokumentu tożsamości (dowodu osobistego lub paszportu). Tymczasem w praktyce przeszkodą do otrzymania takiego dokumentu okazuje się sygnalizowany wcześniej wymóg obligatoryjnej transkrypcji aktu urodzenia (art. 104 ust. 5 p.a.s.c.). Trzeba pamiętać, że krajowy system rejestracji stanu cywilnego jest dostosowany do reguł polskiego prawa rodzinnego, które przewiduje, że rodzicami mogą być wyłącznie kobieta i mężczyzna. Dlatego w polskim akcie stanu cywilnego, podobnie jak w formularzach odpisów aktów, zawsze znajdują się odrębne rubryki dotyczące „matki” $\mathrm{i}$ „ojca”. Problematyczna w związku z tym staje się nie tylko generalna dopuszczalność, lecz także techniczna możliwość sporządzenia polskiego aktu stanu cywilnego na podstawie dokumentu zagranicznego, w którym jako rodziców wpisano osoby tej samej płci.

Orzecznictwo sądów administracyjnych dotyczące poruszonego problemu nie jest jednolite. Sprawy z tego zakresu trafiają na wokandę sądową przede wszystkim wtedy, gdy dojdzie do odmowy transkrypcji. Decyzja kierownika USC podlega wtedy zaskarżeniu do organu wyższego stopnia (wojewody), a następnie możliwe jest złożenie skargi do sądu administracyjnego. Wśród wielu orzeczeń dotyczących rozważanego proble$\mathrm{mu}$, ze zrozumiałych względów, szczególną uwagę wzbudzają rozstrzygnięcia liberalne, w których dopuszczono transkrypcję aktów urodzenia dzieci par jednopłciowych. Przykładem jest wyrok Wojewódzkiego Sądu Administracyjnego w Poznaniu z 5.04.2018 r., II SA/Po 1169/17, w którym sąd opowiedział się za możliwością umiejscowienia aktu urodzenia wskazującego na rodzicielstwo dwóch kobiet. W innej analogicznej sprawie, w wyroku z 10.10.2018 r., II OSK 2552/16, transkrypcję dopuścił też Naczelny Sąd Administracyjny.

Ostatecznie jednak w judykaturze zwyciężyło stanowisko restryktywne, którego najpełniejszym wyrazem jest uchwała 7 sędziów NSA z 2.12.2019 r., II OPS 1/19. Przyjęto w niej, że obowiązujące przepisy, a w szczególności klauzula porządku publicznego przewidziana $\mathrm{w}$ art. 107 pkt 3 p.a.s.c., nie dopuszczają transkrypcji zagranicznego aktu urodzenia dziecka, w którym jako rodzice wpisane są osoby tej samej płci. Jednocześnie Naczelny Sąd Administracyjny wskazał, że „prawidłowa wykładnia art. 104 ust. 5 p.a.s.c. nie może prowadzić do uzależnienia uzyskania przez obywatela polskiego dowodu tożsamości albo numeru PESEL od dokonania przez organ transkrypcji, która nie jest możliwa tylko z tego powodu, że w zagranicznym akcie urodzenia dziecka podano zamiast danych ojca dane kobiety, która pozostaje w nieznanym polskiemu prawu związku". Skład orzekający wyraźnie zasygnalizował zatem, że mimo niedopuszczalności transkrypcji, musi istnieć możliwość 
uzyskania przez dziecko polskiego dowodu tożsamości. Oznacza to, że zasada obligatoryjnej transkrypcji doznaje $\mathrm{w}$ tym przypadku wyjątku. Przy okazji skład orzekający przypomniał powszechnie akceptowany w Polsce pogląd, zgodnie z którym sporządzone za granicą akty stanu cywilnego, jako dokumenty urzędowe, mają moc dowodową zrównaną z aktami polskimi (zob. art. 1138 Kodeksu postępowania cywilnego ${ }^{7}$ ). Co więcej, bezpośrednie zastosowanie znajduje do nich art. 3 p.a.s.c., który przewiduje, że akty stanu cywilnego stanowią wyłączny dowód zdarzeń w nich stwierdzonych ${ }^{8}$. W efekcie także akty zagraniczne mogą być brane pod uwage przy wydawaniu dziecku polskiego dokumentu tożsamości.

Jeśli chodzi o stanowisko doktryny, to zagadnienie doczekało się w literaturze licznych wypowiedzi, przy czym poglądy poszczególnych autorów są bardzo zróżnicowane. Liberalne stanowisko, zakładające potrzebę dopuszczenia transkrypcji aktów urodzenia dzieci par jednopłciowych, reprezentują m.in. M. Zachariasiewicz ${ }^{9}$, J. Pawliczak ${ }^{10}$ czy T.J. Tadla ${ }^{11}$. Na przeciwległym krańcu dyskusji należy odnotować wypowiedzi P. Mostowika ${ }^{12}$, P. Kasprzyka ${ }^{13}$ oraz E. Przyśliwskiej-Urbanek ${ }^{14}$. Także autor niniejszego opracowania wypowiadał się w rozważanej kwestii. Sama uchwała 7 sędziów NSA z 2.12.2019 r. spotkała się z jego ostrożną aprobatą, choć $\mathrm{z}$ istotnymi zastrzeżeniami ${ }^{15}$.

${ }^{7}$ Ustawa z 17.11.1964 r. - Kodeks postępowania cywilnego, t.j. Dz.U. 2020, poz. 1575 [dalej: k.p.c.].

${ }^{8}$ Zob. m.in. uchwałę 7 sędziów SN z 20.11.2012 r., III CZP 58/12; por. także postanowienie SN z 23.07.2015 r., I CSK 725/14.

${ }^{9}$ Zob. M. Zachariasiewicz, Transkrypcja aktów urodzenia dzieci par jednoptciowych, „Studia Prawno-Ekonomiczne” 2019, T. 111, s. 143 i n.

${ }_{10}$ Zob. J. Pawliczak, Dane przestaniajace - nieustalenie ojcostwa, „Metryka” 2020, nr 1 , s. $50-51$.

11 T.J. Tadla, Glosa do wyroków NSA z dnia 10 i 30 października 2018 r., II OSK 1868/16, II OSK 1869/16, II OSK 1870/16, II OSK 2552/16, „Zeszyty Naukowe Sądownictwa Administracyjnego" 2019, z. 3, s. 150-158.

12 Zob. P. Mostowik, Problematyka prawna żadań rejestracji $w$ polskich aktach stanu cywilnego zagranicznej fikcji prawnej pochodzenia dziecka od „rodziców homoseksualnych”, „Metryka” 2019, nr 2, s. 19-60; P. Mostowik, Glosa do wyroku NSA z dnia 10 października 2018 r. (sygn. akt II OSK 2552/16), „Zeszyty Naukowe Sądownictwa Administracyjnego" 2019, z. 4, s. 132-147.

${ }_{13}$ Zob. P. Kasprzyk, w: Podręcznik urzędnika stanu cywilnego, T. 2: Obrót prawny $z$ zagranica $w$ zakresie rejestracji stanu cywilnego, red. P. Kasprzyk, Fundacja Instytut Naukowy im. Prof. Józefa Litwina, Lublin, 2019, s. 311—312.

${ }_{14}$ E. Przyśliwska-Urbanek, Aktualne orzecznictwo sqdów administracyjnych dotyczqce rejestracji pochodzenia dziecka od osób tej samej ptci, w: Kolizyjne i procesowe aspekty prawa rodzinnego, red. J. Gołaczyński, W. Popiołek, C.H. Beck, Warszawa, 2019, s. 151-160.

${ }_{15}$ Zob. M. Wojewoda, Zagraniczne rodzicielstwo osób jednej ptci a rejestracja stanu cywilnego w Polsce - glosa do uchwaty NSA (7) z 2.12.2019 r., II OPS 1/19, „Europejski Przegląd Sądowy" 2020, nr 8, s. 30 i n. 


\section{Akty transkrybowane wbrew stanowisku judykatury?}

Mogłoby się wydawać, że uchwała rozszerzonego składu Naczelnego Sądu Administracyjnego, stwierdzająca niedopuszczalność transkrypcji aktów urodzenia dzieci par jednopłciowych, przesądziła sprawę od strony praktycznej. Ma ona bowiem charakter wiążący dla sądów administracyjnych. Zgodnie z art. $269 \$ 1$ zd. 1 ustawy z 30.08.2012 r. Prawo o postępowaniu przed sądami administracyjnymi ${ }^{16}$, „jeżeli jakikolwiek skład sądu administracyjnego rozpoznający sprawę nie podziela stanowiska zajętego w uchwale składu siedmiu sędziów, całej Izby albo w uchwale pełnego składu NSA, przedstawia powstałe zagadnienie prawne do rozstrzygnięcia odpowiedniemu składowi”. Uchwała 7 sędziów NSA z 2019 r. z pewnością stabilizuje zatem orzecznictwo administracyjne. Wbrew pozorom jednak w rozważanym tu przypadku nie oznacza to definitywnego zamknięcia problemu. Po pierwsze, trzeba odnotować, że w następstwie poprzedniego judykatu NSA z 10.10.2018 r. (II OSK 2552/16), dopuszczającego umiejscowienie aktów urodzenia dzieci par jednopłciowych, w ciągu ponad 12 kolejnych miesięcy, które poprzedziły wydanie uchwały 7 sędziów, w całej Polsce doszło do transkrypcji wielu takich aktów. Pojawia się zatem pytanie, jakie mają być losy tych dokumentów w świetle obecnego stanowiska judykatury. Po drugie zaś, trzeba zauważyć, że związanie uchwałą rozszerzonego składu NSA nie dotyczy wprost kierownika USC. Może się zatem okazać, że - choćby ze względu na brak znajomości stanowiska NSA - okazjonalnie nadal będzie dochodzić do umiejscowienia zagranicznych aktów urodzenia dzieci par jednopłciowych ${ }^{17}$. We wszystkich tych przypadkach należy rozstrzygnąć, czy istnieje potrzeba oraz możliwość podważenia aktu stanu cywilnego sporządzonego w polskim rejestrze.

Należy z góry zaznaczyć, że nie bez znaczenia jest to, w jaki technicznie sposób dokonano umiejscowienia. Doświadczenie wskazuje, że w polskich aktach urodzenia dzieci par jednopłciowych, które zostały sporządzone w trybie transkrypcji, różnie przedstawia się sposób określenia rodzicielstwa. Zrozumiałe wydaje się, że w polskim akcie nie zostają wypełnione rubryki dotyczące obojga rodziców. Jeżeli, zgodnie z zagranicznym dokumentem, dziecko ma dwie matki, to w krajowym ak-

16 T.j. Dz.U. 2019, poz. 2325 [dalej: p.p.s.a.].

17 Warto przypomnieć, że urząd stanu cywilnego jest w każdej gminie (art. 6 p.a.s.c.). Mamy zatem w Polsce niemal dwa i pół tysiąca takich urzędów. Niektóre z nich mają bardzo niewielką praktykę dotyczącą transkrypcji zagranicznych aktów stanu cywilnego. 
cie zazwyczaj ujawnia się kobietę, która dziecko urodziła. Z perspektywy prawa polskiego (które jest najczęściej właściwe dla oceny pochodzenia dziecka ${ }^{18}$ ) właśnie ta kobieta jest matką (zob. art. $61^{9}$ k.r.o.). Otwarte pozostaje jednak pytanie, jak należy wypełnić rubrykę „ojciec” oraz w jaki sposób ujawnić ewentualnie drugiego rodzica tej samej płci. W grę wchodzi kilka opcji. W powoływanym już wyżej wyroku WSA w Poznaniu z 5.04.2018 r. (II SA/Po 1169/17) przyjęto, że dopuszczalnym sposobem transkrypcji aktu jest wpisanie do polskiego rejestru tylko jednego z rodziców, z pozostawieniem drugiej rubryki wolnej (bez jakiejkolwiek wzmianki o drugim rodzicu ${ }^{19}$. Z kolei w sprawie, której dotyczył wyrok NSA z 10.10.2018 r. (II OSK 2552/16) przyjęto inne rozwiązanie. Gdy w wykonaniu orzeczenia doszło do sporządzenia aktu urodzenia, to wprawdzie nie uzupełniono rubryki dotyczącej ojca, ale w ramach stosownej adnotacji, zamieszczonej pod aktem, wpisano dane drugiego rodzica tej samej płci. W praktyce w niektórych urzędach stanu cywilnego stosowano jeszcze inne rozwiązanie. Drugi rodzic z aktu źródłowego w ogóle nie był ujawniany, natomiast w rubryce „ojciec” wpisywano tzw. dane kryjące z powołaniem się na art. 61 ust. 2 p.a.s.c. ${ }^{20}$ Autorowi nie są natomiast znane przypadki, w których rubryka „ojciec” zostałaby wypełniona danymi kobiety jako drugiego rodzica, według treści zagranicznego aktu. $\mathrm{O}$ wiele większe problemy pojawiają się, jeżeli w obcym akcie urodzenia rodzicielstwo przypisano dwóm mężczyznom. Jak będzie jeszcze o tym mowa, w tym ostatnim przypadku zarówno przepisanie, jak i ewentualne pozostawienie w obrocie prawnym sporządzonego w polskim rejestrze aktu urodzenia jest wątpliwe, niezależnie od tego, w jaki technicznie sposób miałaby nastąpić transkrypcja ${ }^{21}$.

Po dokonaniu powyższych wstępnych ustaleń należy szczegółowo rozważyć, jakie konkretnie instrumenty mogłyby służyć podważeniu aktów,

18 Jak już powiedziano, jeżeli dziecko rodzi obywatelka Polski, to nabywa ono ex lege polskie obywatelstwo (art. 14 pkt 1 ustawy o obywatelstwie polskim). Prawo polskie jest wtedy właściwe dla ustalenia pochodzenia dziecka (art. 55 p.p.m.).

${ }_{19}$ Należy zaznaczyć, że w rozpatrywanej przez WSA sprawie taki sposób sporządzenia aktu urodzenia (pomijający drugiego rodzica) był zgodny z treścią wniosku o transkrypcję.

${ }^{20}$ Zgodnie z art. 61 ust. 2 p.a.s.c., ,jeżeli nie nastąpiło uznanie ojcostwa albo sądowe ustalenie ojcostwa, w akcie urodzenia zamieszcza się jako imię ojca imię wskazane przez osobę zgłaszającą urodzenie, a w razie braku takiego wskazania w akcie urodzenia zamieszcza się jako imię ojca imię wybrane przez kierownika urzędu stanu cywilnego; jako nazwisko ojca i jego nazwisko rodowe zamieszcza się nazwisko matki z chwili urodzenia dziecka, z adnotacją o wpisaniu nazwiska matki i wybranego imienia jako danych ojca".

${ }^{21}$ Zob. wyr. WSA w Łodzi z 5.02.2020, III SA/Łd 617/19, stwierdzający niedopuszczalność transkrypcji zagranicznego dokumentu stanu cywilnego, w którym jako rodziców wskazano dwóch mężczyzn. 
które - wbrew aktualnemu stanowisku wyrażonemu w uchwale 7 sędziów NSA — zostały umiejscowione w Polsce.

\section{Podważenie aktu stanu cywilnego wpisanego do krajowego rejestru [ze szczególnym uwzględnieniem aktów transkrybowanych)}

Zgodnie z art. 2 ust. 3 i 4 p.a.s.c., „Aktem stanu cywilnego jest wpis o urodzeniu, małżeństwie albo zgonie w rejestrze stanu cywilnego wraz z treścią późniejszych wpisów wpływających na treść lub ważność tego aktu. Akt stanu cywilnego jest sporządzony z chwilą dokonania wpisu o urodzeniu, małżeństwie albo zgonie w rejestrze stanu cywilnego". Jak wynika natomiast $\mathrm{z}$ art. 5 ust. 1 i 2 p.a.s.c., sam rejestr jest prowadzony w systemie teleinformatycznym, a jego utrzymanie i rozwój zapewnia minister właściwy do spraw informatyzacji.

Treść powołanych przepisów pokazuje, że ustawa z 2014 r. odeszła od tradycyjnych metod rejestracji, opartych na systemie papierowych ksiąg stanu cywilnego. Mimo przejścia na model rejestracji elektronicznej, pamiętając o szerokiej definicji dokumentu zawartej w art. $77^{3}$ Kodeksu cywilnego ${ }^{22}$, zgodnie z którym „Dokumentem jest nośnik informacji umożliwiający zapoznanie się z jej treścią", wypada stwierdzić, że także obecnie akt stanu cywilnego jest dokumentem, choć szczególnego rodzaju. Od strony technicznej jego specyfika polega na tym, że obejmuje on wpisy dokonane w systemie teleinformatycznym. Znacznie bardziej istotna jest jednak charakterystyka aktów stanu cywilnego od strony merytorycznej. Sprowadza się ona do kilku ważnych zasad.

Po pierwsze, akt stanu cywilnego jest dokumentem, któremu przyznano szczególną moc dowodową. Jest to dokument urzędowy w rozumieniu art. 244 k.p.c., który jednocześnie stanowi wyłączny dowód zdarzeń w nim stwierdzonych, co wprost wynika $\mathrm{z}$ art. 3 p.a.s.c. Oznacza to, że okoliczności podlegające stwierdzeniu w akcie stanu cywilnego, takie jak: urodzenie, małżeństwo i zgon, nie mogą być urzędowo wykazane w żaden inny sposób niż przez akt stanu cywilnego. Jednak w związku z faktem, że bezpośredni dostęp do samego rejestru i zawartych w nim aktów jest istotnie ograniczony (zob. art. 5 ust. 5 oraz art. 5 a p.a.s.c. ${ }^{23}$ )

${ }^{22}$ Ustawa z 23.04.1964 r. — Kodeks cywilny, t.j. Dz.U. 2020, poz. 1740.

${ }^{23}$ Dostęp do rejestru stanu cywilnego, w celu realizacji zadań określonych w ustawie, mają: kierownik urzędu stanu cywilnego, zastępca kierownika urzędu stanu cywil- 
w bieżącym obrocie funkcję wyłącznych dowodów pełnią w praktyce odpisy z rejestru, które mają walor zrównany z oryginałem ${ }^{24}$. Ich wydawanie regulują art. $44 \mathrm{i}$ n. p.a.s.c.

Po wtóre jednak, nie wolno zapominać, że akty stanu cywilnego mają charakter wyłącznie deklaratywny. Wpisy w rejestrze stanu cywilnego nie konstytuują nowego stanu prawnego $0^{25}$. Wpisy te sa jedynie odbiciem zdarzeń naturalnych, czynności prawnych, orzeczeń sądów oraz decyzji właściwych organów, z których wynika stan cywilny danej osoby ujawniony $\mathrm{w}$ akcie (zob. art. 2 ust. 1 p.a.s.c.). Skutki prawne są zawsze powiązane z określonymi zdarzeniami prawnymi, które mają miejsce „poza rejestrem”.

Po trzecie wreszcie, co stanowi wypadkową dwóch cech wymienionych powyżej, akt stanu cywilnego - jako dokument zaufania publicznego - jest w szczególny sposób chroniony przez prawo. Usuwanie wadliwości aktów, podobnie jak ich aktualizowanie, jest z jednej strony niezbędne, aby mogły one prawidłowo pełnić swoją funkcję dowodową, ale z drugiej strony jest bardzo sformalizowane. W literaturze mówi się o zasadzie trwałości aktu stanu cywilnego ${ }^{26}$. W szczególności podważenie aktu może się dokonać tylko ze ściśle określonych powodów i w ściśle określonej procedurze. Reguła taka znajduje wyraz m.in. w treści art. 3 zd. 2 p.a.s.c., który stanowi, że niezgodność aktu stanu cywilnego $\mathrm{z}$ prawdą może być udowodniona jedynie w postępowaniu sądowym. Musi to być postępowanie nakierowane bezpośrednio na podważenie prawdziwości aktu. Nie wystarczy, że określone okoliczności są w danej sprawie badane przez sąd przesłankowo. Przede wszystkim w art. 3 ust. 2 p.a.s.c. nie chodzi o postępowania sądowe, w których akt stanu cywilnego przedstawiono jako dowód, który został następnie zakwestionowany przez stronę ${ }^{27}$.

Przytoczone uwagi pozwalają postawić tezę, że każdy akt stanu cywilnego, który powstaje w ramach czynności dokonanej przez kierownika

nego, wojewoda, minister właściwy do spraw wewnętrznych oraz minister właściwy do spraw informatyzacji (art. 5 ust. 5 p.a.s.c.). Dodatkowo art. 5 a p.a.s.c. przewiduje możliwość udostępniania danych z rejestru określonym służbom.

${ }^{24}$ Por. J. Ignatowicz, M. Nazar, Prawo rodzinne, Wolters Kluwer, Warszawa, 2016, s. 134.

${ }^{25}$ Jedynym wyjątkiem jest sporządzenie aktu małżeństwa w przypadku tzw. małżeństwa „konkordatowego”, kiedy to zgodnie z art. $1 \S 2$ k.r.o. warunkiem istnienia małżeństwa jest sporządzenie aktu małżeństwa, tak SN w wyr. z 3.03.2004, III CK 346/02; por. także G. Jędrejek, Kodeks rodzinny i opiekuńczy. Komentarz aktualizowany, Lex/el. 2019, uwagi do art. 1 k.r.o., pkt 2.

${ }^{26}$ A. Czajkowska, w: I. Basior, A. Czajkowska, D. Sorbian, Prawo o aktach stanu cywilnego z komentarzem, Wolters Kluwer, Warszawa, 2015, s. 75.

${ }_{27}$ Zob. K. Gondorek, A. Ustowska, Prawo o aktach stanu cywilnego z komentarzem, Wydawnictwo Prawnicze, Warszawa, 1991, s. 47. 
USC, z chwilą jego sporządzenia w rejestrze i (elektronicznego) podpisania zaczyna „żyć własnym życiem”. Akt stanu cywilnego stanowi szczególnego rodzaju konstrukcję jurydyczną — jest to akt prawnie doniosły. Odrywa się on od czynności i procedur, jakie doprowadziły do jego powstania. Potencjalna wadliwość tych procedur sama przez się nie wpływa na losy dokumentu. Jeżeli dany wpis w rejestrze jest rzeczywiście aktem stanu cywilnego - tzn. dotyczy urodzenia, małżeństwa lub zgonu i został sporządzony przez osobę piastującą funkcję kierownika USC lub jego zastępcę ${ }^{28}$ - to jego wyeliminowanie z obrotu może nastąpić wyłącznie na podstawie wyraźnie przewidujących to przepisów. W szczególności, do upadku aktu nie prowadzi zaskarżenie czynności kierownika USC, która była niezbędna, aby akt zaistniał. Takiego skutku nie przewiduje bowiem żaden przepis prawa. Co więcej, można mieć wątpliwości, czy sama czynność kierownika USC, polegająca na sporządzeniu aktu stanu cywilnego, w ogóle podlega zaskarżeniu ${ }^{29}$.

Powyższe uwagi dotyczą zarówno aktów sporządzonych w trybie pierwotnej rejestracji, jak i aktów będących wynikiem transkrypcji, gdy w ramach czynności materialno-technicznej dochodzi do przepisania zagranicznego dokumentu (art. 105 ust. 1 p.a.s.c.) ${ }^{30}$. Polski akt będący wynikiem umiejscowienia jest bowiem traktowany jak każdy inny akt stanu cywilnego sporządzony w krajowym rejestrze ${ }^{31}$.

Podstawy podważenia aktu stanu cywilnego są bardzo ograniczone. Już na wstępie należy odnotować, że w aktualnym stanie prawnym nie istnieje jakakolwiek procedura, która pozwalałaby na „uchylenie” aktu stanu cywilnego, jego „skreślenie” albo „uznanie za bezskuteczny". Gdy chodzi o konstrukcje, jakie przewidział ustawodawca i które w wyjątkowych przypadkach dochodzą do głosu, to można je podzielić na dwie grupy.

Część regulacji dotyczy sytuacji szczególnych, odnoszących się do konkretnego typu aktu dotkniętego danym rodzajem wadliwości. I tak

${ }^{28}$ Zgodnie z art. 5 ust. 1 p.a.s.c., „wpisu w rejestrze stanu cywilnego dokonuje kierownik urzędu stanu cywilnego lub zastępca kierownika urzędu stanu cywilnego". Dodatkowo art. 9 ust. 1 p.a.s.c. stanowi, że „czynności z zakresu rejestracji stanu cywilnego są dokonywane przez kierownika urzędu stanu cywilnego lub zastępcę kierownika urzędu stanu cywilnego".

${ }^{29}$ Zob. uwagi w pkt. 5 niniejszego opracowania.

30 Transkrypcja ma charakter reprodukcyjny i sprowadza się do sporządzenia aktu krajowego, reprodukującego treść aktu zagranicznego. Czynność kierownika USC nie ma charakteru pierwotnej rejestracji, gdyż ta nastąpiła już za granicą, zob. M. Wojewoda, Transkrypcja zagranicznego dokumentu stanu cywilnego - kilka uwag na temat ewolucji konstrukcji w prawie polskim, „Metryka” 2016, nr 2, s. 54 oraz powołana tam literatura.

${ }^{31}$ M. Wojewoda, Transkrypcja..., s. 53. 
w razie uchylenia postanowienia sądu o stwierdzeniu zgonu lub o uznaniu za zmarłego, jeżeli okazało się, że dana osoba żyje, konieczne jest podważenie aktu zgonu sporządzonego na podstawie powołanych postanowień. Jest oczywiste, że w obrocie nie powinien funkcjonować urzędowy dowód śmierci osoby żyjącej. Praktyka przyjmuje, że po uchyleniu postanowienia $\mathrm{w}$ akcie zgonu umieszcza się stosowną wzmiankę dodatkową, a sam akt, zgodnie z art. 95 ust. 6 p.a.s.c., „nie podlega ujawnieniu i nie wydaje się odpisów tego aktu".

Inny przykład dotyczy sytuacji, gdy dla dziecka sporządzono nowy akt urodzenia - czy to w następstwie adopcji (zob. art. 71 ust. 1 oraz art. 71 ust. 3 p.a.s.c.), czy też po obaleniu domniemania ojcostwa męża matki (art. 67 ust. 1 p.a.s.c.). Pojawia się wtedy pytanie o losy aktu pierwotnego, który nie może dalej pełnić swej funkcji dowodowej. Przepisy przewidują, że do takiego aktu dołącza się wzmiankę dodatkową o sporządzeniu nowego aktu urodzenia. Także w tych przypadkach akt pozostaje jednak w rejestrze, a jedynie nie podlega ujawnieniu (zob. art. 73 ust. 1 oraz art. 67 ust. 4 p.a.s.c.). Można powołać jeszcze jeden przykład, tym razem dotyczący aktu małżeństwa. Jeżeli akt został sporządzony, mimo że nie doszło do złożenia przez nupturientów oświadczeń o wstąpieniu $\mathrm{w}$ związek małżeński, to w specjalnym postępowaniu sądowym małżeństwo może być uznane za nieistniejące (zob. art. 2 k.r.o.). Następnie w akcie małżeństwa wpisuje się wzmiankę dodatkową o prawomocnym wyroku. W tym przypadku akt nie tylko pozostaje w rejestrze, lecz nadal można uzyskać jego odpis. Naturalnie odpis taki zostaje wydany $\mathrm{z}$ odpowiednim oznaczeniem, że małżeństwo uznano za matrimonium non existens ${ }^{32}$.

Żadna z powołanych przed chwilą konstrukcji szczególnych nie znajduje jednak odniesienia do aktów urodzenia wprowadzonych do polskiego rejestru w trybie transkrypcji, których zagranicznym pierwowzorem był dokument wskazujący na pochodzenie dziecka od rodziców jednopłciowych. W tym przypadku w grę może wejść inny, tym razem ogólny, mechanizm przewidziany w Prawie o aktach stanu cywilnego z $2014 \mathrm{r}$. Chodzi o instytucję unieważnienia aktu stanu cywilnego. Umożliwia ona wyeliminowanie aktu z obrotu prawnego w przypadkach nieobjętych regulacją legum specialis. Instytucji tej należy poświęcić osobny punkt rozważań.

${ }^{32}$ Zob. art. 48 ust. 3 pkt 7 p.a.s.c., gdy chodzi o odpis skrócony aktu małżeństwa, oraz art. 44 ust. 2 p.a.s.c., gdy chodzi o odpis zupełny. 


\section{Unieważnienie aktu stanu cywilnego}

Ustawodawca przewidział dwa tryby unieważnienia aktu. W określonych sytuacjach, w których doszło do błędów o charakterze „technicznym", w tym zwłaszcza gdy sporządzono dwa akty obejmujące to samo zdarzenie, unieważnienie dokonuje się w trybie administracyjnym. Chodzi o regulację zawartą w art. 39a i 39b p.a.s.c., a także w art. 127 ust. 2 i 3 p.a.s.c. oraz w art. 127 a p.a.s.c. Kompetencję do unieważnienia aktu stanu cywilnego przyznano wojewodzie lub (w sytuacjach najbardziej oczywistych) samemu kierownikowi USC ${ }^{33}$. Unieważnienie może się dokonać także z urzędu.

W odniesieniu do powstałych w drodze transkrypcji aktów stanu cywilnego dzieci par jednopłciowych rozważyć jednak należy drugi tryb unieważnienia, jaki uregulowano w ustawie. Chodzi o podważenie aktu z powodów „merytorycznych”. Stanowi o tym art. 39 p.a.s.c. Powołany przepis daje możliwość unieważnienia aktu stanu cywilnego lub dołączonej do niego wzmianki dodatkowej przez sąd powszechny w postępowaniu nieprocesowym przy spełnieniu jednej z dwóch alternatywnych przesłanek. Pierwszą z nich jest okoliczność, że akt potwierdza „zdarzenie niezgodne ze stanem faktycznym”, a drugą — okoliczność, że „stwierdzono uchybienia, które zmniejszają jego moc dowodową".

Jeśli chodzi o pierwszą przesłankę, to o zdarzeniu niezgodnym z prawdą mówimy wtedy, gdy w ogóle nie doszło do urodzenia dziecka lub do zawarcia małżeństwa, albo gdy sporządzono akt zgonu osoby, która żyje. Potrzeba unieważnienia aktu wydaje się wtedy oczywista (z zastrzeżeniem pierwszeństwa powołanych wyżej przepisów szczególnych $^{34}$ ). Co jednak znamienne, unieważniony akt stanu cywilnego zawsze pozostaje $\mathrm{w}$ rejestrze. Ustawa zastrzega jedynie, że nie podlega on ujawnieniu i co do zasady nie wydaje się z niego odpisów (zob. art. 42 p.a.s.c.).

Wracając do przesłanek $\mathrm{z}$ art. 39 p.a.s.c., druga $\mathrm{z}$ nich ma nieco inny charakter. Przepis stanowi o uchybieniach, które zmniejszają moc dowodową aktu. W literaturze i w orzecznictwie wskazuje się, że może tu chodzić np. o sporządzenie aktu przez osobę nieuprawnioną, o umiejscowienie zagranicznego dokumentu, który nie jest aktem stanu cywilnego, lub

${ }^{33}$ Obecność w ustawie powołanych przepisów wskazuje na wyjątki od powoływanej wcześniej zasady, wynikającej z art. 3 zd. 2 in fine p.a.s.c., zgodnie z którą niezgodność aktu stanu cywilnego z prawdą może być udowodniona jedynie w postępowaniu sądowym.

${ }^{34}$ Chodzi zwłaszcza o art. 2 k.r.o. przy akcie małżeństwa i art. 95 ust. 6 p.a.s.c. przy akcie zgonu. 
o zarejestrowanie w formie aktu stanu cywilnego zdarzenia, które nie jest w Polsce przedmiotem rejestracji ${ }^{35}$.

Odnosząc powyższe uwagi do aktów urodzenia dzieci par jednopłciowych, które zostały umiejscowione w polskim rejestrze, trzeba stwierdzić, że w grę nie wchodzi z pewnością przesłanka pierwsza. W sprawach, o których mowa, nie jest kwestionowany fakt urodzenia dziecka $\mathrm{w}$ danym miejscu i czasie. Odnotowane w rejestrze zdarzenia są niewątpliwie zgodne z prawdą. Pozostaje zatem ocenić, czy sposób sporządzenia aktu urodzenia, a zwłaszcza określenie w nim rodzicielstwa, nie podważa mocy dowodowej dokumentu.

Analizę wypada rozpocząć od przypomnienia, że wyłączność dowodowa aktów stanu cywilnego w zakresie zdarzeń w nich stwierdzonych (art. 3 p.a.s.c.) dotyczy nie tylko samego faktu urodzenia, małżeństwa czy zgonu, ale także niektórych innych danych zawartych w akcie. Jak podkreślił Sąd Najwyższy w wyroku z 11.12.2002 r. (I CK 348/02), w przypadku aktu urodzenia hipotezą art. 3 p.a.s.c. są objęte wszystkie podstawowe dane dotyczące dziecka, takie jak: płeć, imię, nazwisko oraz, co szczególnie istotne, pochodzenie od określonych rodziców ${ }^{36}$. Brak określenia rodzicielstwa lub występujące w tym zakresie nieprawidłowości mogą być zatem potencjalnie odbierane jako podważające moc dowodową aktu ${ }^{37}$.

Wydaje się jednak, że sama tylko okoliczność, że w polskim akcie urodzenia nie wpisano obojga rodziców dziecka, lub że wpis wygląda inaczej niż w źródłowym dokumencie zagranicznym nie jest wystarczającą podstawą dla unieważnienia aktu. Warto zwrócić uwagę na postanowienie Sądu Najwyższego z 26.03.1992 r. (I CRN 20/92) ${ }^{38}$. W uzasadnieniu Sąd Najwyższy podkreślił, że procedura unieważnienia aktu może dotyczyć tylko niezgodności z prawdą „zdarzenia podstawowego”, jakim jest sam fakt urodzin, zawarcia małżeństwa lub zgonu. Wyraźnie zaznaczono, że „inne przypadki niezgodności aktu z rzeczywistością [...], związane ze

${ }^{35}$ Por. A. Czajkowska, w: I. Basior, A. Czajkowska, D. Sorbian, Prawo o aktach..., s. 88

${ }^{36}$ Wyrok odnosił się do art. 4 Prawa o aktach stanu cywilnego z 29.09.1986 r. (Dz.U. 1986, nr 36, poz. 180 ze zm.), ale zachował pełną aktualność, gdyż obecnie obowiązujący art. 3 p.a.s.c. stanowi dosłowne powtórzenie wcześniejszej regulacji.

${ }^{37}$ Co istotne, nie dotyczy to aktu małżeństwa i zgonu, w których oznaczenie rodziców małżonka lub zmarłego ma jedynie znaczenie identyfikujące, por. M. Wojewoda, w: System Prawa Prywatnego, T. 20C, Prawo prywatne międzynarodowe, red. M. Pazdan, C.H. Beck, Warszawa, 2015, s. 549-550. Kwestia ta będzie jeszcze przedmiotem uwag w dalszej części opracowania, w kontekście umieszczania informacji o rodzicach tej samej płci w aktach stanu cywilnego innych niż akt urodzenia.

38 Także to orzeczenie zapadło pod rządami ustawy Prawo o aktach stanu cywilnego z 1986 r., ale zachowuje aktualność w obecnym stanie prawnym. 
zdarzeniami mającymi wpływ na stan cywilny osób i dotyczące w istocie tylko elementów aktu (np. miejsce lub data zdarzenia, dane o rodzicach osoby, nazwisko, płeć itp.), mogą być jedynie przedmiotem sprostowania”.

W świetle powołanych orzeczeń, zdaniem autora, należy przyjąć tezę, że we wszystkich przypadkach, w których w akcie urodzenia wpisano kobietę, która dziecko urodziła, dokument posiada wystarczającą moc dowodową. Jeśli drugi rodzic został ujawniony chociażby w adnotacji, to trudno w ogóle mówić o niezgodności aktu krajowego i obcego. Transkrypcją rządzi wprawdzie ważna zasada wiernego przepisania aktu (art. 104 ust. 2 p.a.s.c.), ale, jak się podkreśla, powinna być ona realizowana w sposób elastyczny, uwzględniający odmienności rejestracyjne i różnice $\mathrm{w}$ przepisach merytorycznych, jakie obowiązują w Polsce i w państwie pochodzenia aktu ${ }^{39}$. Chodzi o uwzględnienie funkcji określonych wpisów ${ }^{40}$. W przypadku zagranicznego rodzicielstwa dwóch kobiet ewentualne wpisanie drugiego rodzica tej samej płci w adnotacji pod aktem nie narusza zasad transkrypcji i nie umniejsza roli sporządzonego aktu urodzenia. Takie rozwiązanie wynika z faktu, że polski akt zawiera rubrykę „ojciec”, w której może być wpisany tylko mężczyzna. Nawet jednak, jeżeli drugi rodzic w ogóle nie został wpisany, to podobny brak nie powinien powodować unieważnienia aktu. W takim bowiem przypadku, jak będzie o tym dalej mowa, można dokonać sprostowania, ujawniając drugiego rodzica tej samej płci $\mathrm{w}$ adnotacji ${ }^{41}$. Taką drogę usuwania niektórych braków aktów stanu cywilnego wyraźnie wskazuje Sąd Najwyższy w powołanym wcześniej orzeczeniu z $1992 \mathrm{r}$.

Zdaniem autora, rzeczywisty problem dotyczy jedynie tych przypadków, w których w polskim akcie nie zostaje ujawniona matka, która urodziła dziecko. Chodzi przede wszystkim o obce akty stanu cywilnego, w których jako rodziców wskazano dwóch mężczyzn. W tym przypadku oznaczenie w polskim rejestrze pochodzenia dziecka w sposób dający się pogodzić z założeniami polskiego prawa rodzinnego nie wydaje się możliwie. Według Kodeksu rodzinnego i opiekuńczego, aby ustalić rodziców, najpierw trzeba wskazać matkę, bo ojcostwo jest zawsze „pochodną macierzyństwa" ${ }^{2}$. Istnieje zatem silny argument, by nie przepisywać takich dokumentów do krajowego rejestru, bo z punktu widzenia prawa polskiego od początku oczywiste będą zastrzeżenia dowodowe dotyczące filiacji. Tym bardziej wątpliwości budzi przepisanie obcego aktu, w któ-

${ }^{39}$ Por. M. Wojewoda, w: System..., T. 20C, s. 601.

40 Zob. postanowienie SN z 8.05.2015, III CSK 296/14; podobnie NSA w wyr. z 29.08.2018, II OSK 2129/16; por. też T.J. Tadla, Glosa do wyroków..., s. 157.

${ }^{41}$ Zob. uwagi w pkt. 6 niniejszego opracowania.

${ }^{42}$ Zob. T. Smyczyński, w: System Prawa Prywatnego, T. 12, Prawo rodzinne i opiekuńcze, red. T. Smyczyński, C.H. Beck, Warszawa, 2011, s. 9. 
rym ujawniono tylko mężczyznę (w roli ojca), bez wskazania matki ani drugiego rodzica ${ }^{43}$. Nawet jeśli istnieje dowód genetycznego pochodzenia dziecka od tego mężczyzny, to nie jest to wystarczające. Z punktu widzenia prawa polskiego bowiem sama więź genetyczna nie jest bezpośrednim źródłem prawnej relacji rodzicielskiej ${ }^{44}$. Dlatego też, gdyby został sporządzony w Polsce akt urodzenia dziecka, którego rodzicami — zgodnie ze źródłowym dokumentem zagranicznym — są dwie osoby płci męskiej, to niezależnie od tego, w jaki sposób wpisano w tym akcie dane rodziców, nie będzie on miał wystarczającej mocy dowodowej. Patrząc z polskiej perspektywy, brak przesądzenia macierzyństwa jest jednoznaczny z generalnym nieustaleniem filiacji. Przyjmując restryktywne podejście, wobec braku wskazania osób, które zgodnie z prawem polskim mogą być uznane za rodziców dziecka, akt urodzenia mógłby podlegać unieważnieniu na podstawie art. 39 p.a.s.c. ${ }^{45}$ To samo dotyczy rodzicielstwa osób jednej płci (zarówno mężczyzn, jak i kobiet), wynikającego z obcych procedur surogacyjnych lub z przysposobienia. Umowy o macierzyństwo zastępcze, podobnie jak zagraniczne orzeczenia przyznające tzw. rodzicom socjologicznym prawa rodzicielskie, nie mogą być w Polsce uznane za legalny sposób nawiązania więzi rodzicielskiej ${ }^{46}$. Także orzeczenia adopcyjne dotyczące par jednopłciowych wywołują w Polsce zastrzeżenia.

Oczywiście we wszystkich przypadkach, w których nie ma polskiego aktu urodzenia, pochodzenie dziecka może być wykazywane za pomocą źródłowego aktu zagranicznego, który posiada w Polsce moc dowodową zrównaną z aktami krajowymi (art. 1138 k.p.c. w zw. z art. 4 p.a.s.c.). Wtedy oczywiste jest jednak, że chodzi o relację wynikającą z prawa obcego, która w Polsce nie musi podlegać uznaniu ${ }^{47}$. Nie wydaje się nato-

${ }^{43} \mathrm{Na}$ niedopuszczalność transkrypcji w takim przypadku wskazuje wyr. NSA z 10.09.2020, II OSK 1390/18. Możliwość taką zaakceptował jednak NSA w kontrowersyjnym wyr. z 29.08.2018, II OSK 2129/16.

44 Jurydyczna więź rodzicielska powinna wprawdzie odpowiadać więzi genetycznej, ale ta ostatnia ma znaczenie tylko pośrednie. Aktualnie o prawnym pochodzeniu dziecka od określonego mężczyzny decydują: urodzenie w małżeństwie (art. 62 k.r.o.), czynność uznania ojcostwa (art. 73 k.r.o.) lub orzeczenie sądowe ustalające ojcostwo (art. 84 i n. k.r.o.).

${ }_{45}$ Podobnie przedstawia się sytuacja w przypadku aktów urodzenia dzieci z surogacji, zob. M. Wojewoda, Macierzyństwo zastępcze a rejestracja stanu cywilnego w Polsce, w: Fundamentalne prawne problemy „surrogate motherhood”. Perspektywa krajowa, red P. Mostowik, Wydawnictwo Instytutu Wymiaru Sprawiedliwości, Warszawa, 2019, s. 514 i n.

${ }_{46}$ Por. G. Jędrejek, Kodeks..., uwagi do art. 519 k.r.o., pkt 2. Jeśli chodzi o próby ustalenia, na podstawie prawa polskiego, pochodzenia dziecka urodzonego przez tzw. surogatkę, zob. P. Telesiewicz, „Surrogate motherhood” (urodzenie zastępcze) na tle fundamentów materialnego prawa rodzinnego, w: Fundamentalne..., s. 497 i n.

${ }_{47}$ Należy przy tym dostrzec, że w przypadku zagranicznych związków jednopłciowych oraz relacji filiacyjnych dotyczących takich związków samo pojęcie uznania jest wyjątkowo nieostre. 
miast zasadne tworzenie polskiego aktu urodzenia dziecka, skoro w odniesieniu do zagranicznych wpisów dotyczących filiacji brak jest możliwości przyznania im odpowiedniego poziomu krajowej „nostryfikacji”.

Powyższe zastrzeżenia co do mocy dowodowej nie dotyczą, jak już powiedziano, transkrybowanych aktów urodzenia, w których jako matkę wskazano kobietę, która dziecko urodziła. Z perspektywy prawa polskiego kwestia macierzyństwa nie budzi tu wątpliwości. Można więc uznać, że akt urodzenia w wystarczającym zakresie wypełnia swą funkcję wyłącznego dowodu zdarzeń w nim stwierdzonych, co w pełni uzasadnia pozostawienie go w obrocie. Naturalnie potwierdzenie urodzenia dziecka przez daną kobietę nie musi wprost wynikać z treści zagranicznego $a \operatorname{lu}^{48}$, lecz może być także udowodnione odrębnie (np. zaświadczeniem lekarskim), w ramach postępowania wyjaśniającego prowadzonego przez kierownika USC (art. 22 p.a.s.c.).

Nieco na marginesie należy dodać, że w niektórych przypadkach podejście do wpisania rodziców jednopłciowych w polskim rejestrze stanu cywilnego powinno być jeszcze bardziej elastyczne. I tak można sobie wyobrazić, że osoba urodzona za granicą, w której obcym akcie urodzenia jako rodzice figurują dwie kobiety lub dwóch mężczyzn, zawiera w Polsce związek małżeński. Analogicznie, może chodzić o zgon takiej osoby na terytorium RP. Pojawia się wtedy problem sporządzenia polskiego aktu małżeństwa lub zgonu. Sam obowiązek zarejestrowania takich krajowych zdarzeń w rejestrze stanu cywilnego nie może budzić żadnych wątpliwości ${ }^{49}$. Sytuacja jest tu o tyle inna — w porównaniu z rozważaną wcześniej transkrypcją aktu urodzenia - że ani akt małżeństwa, ani akt zgonu nie są dowodami relacji rodzicielskiej ${ }^{50}$. Ustawa przewiduje wprawdzie wpisanie do aktu danych rodziców małżonka czy rodziców zmarłego (są w tym celu przewidziane odpowiednie rubryki ${ }^{51}$ ), ale ma to przede wszystkim na celu identyfikację danej osoby. Nie cho-

${ }^{48}$ Takie rozwiązanie przyjęto np. w prawie holenderskim — gdy w akcie urodzenia jako rodzice są ujawnione dwie kobiety, zaznacza się, która z nich urodziła dziecko. W aktach angielskich z kolei pojawiają się odrębne oznaczenia „matka” oraz „rodzic”.

${ }^{49}$ Zgodnie z art. 86 ust. 1 p.a.s.c., kierownik USC, który przyjął oświadczenia o wstąpieniu w związek małżeński, sporządza akt małżeństwa najpóźniej w następnym dniu roboczym. Gdy chodzi natomiast o zgony na terenie RP, to z art. 16 p.a.s.c. wynika, że zgłoszenia zgonu dokonuje się w urzędzie stanu cywilnego właściwym ze względu na miejsce zgonu albo miejsce znalezienia zwłok. Zgodnie natomiast z art. 92 ust. 1 p.a.s.c., akt zgonu sporządza się w dniu, w którym dokonano zgłoszenia, a w wyjątkowych przypadkach - w następnym dniu roboczym.

${ }_{50}$ Zob. M. Wojewoda, w: System..., T. 20C, s. 549-550 i powołana tam literatura, por. J. Ignatowicz, M. Nazar, Prawo rodzinne..., s. 133-134.

${ }_{51}$ Zob. art. 88 ust. 1 pkt 3 oraz art. 95 ust. 1 pkt 5 p.a.s.c., które przewidują wpisanie danych rodziców odpowiednio w akcie małżeństwa oraz w akcie zgonu. 
dzi zaś o urzędowe poświadczenie filiacji. Nie dojdzie zatem do podważenia mocy dowodowej aktu, jeżeli rubryki dotyczące ojca i matki pozostaną puste, a dane rodziców jednopłciowych (ustalone na podstawie zagranicznych dokumentów) będą podane tylko w ramach adnotacji. Właśnie takie techniczne rozwiązanie wydaje się tu najbardziej właściwe ${ }^{52}$. W rozważanym przypadku wskazanie rodziców pod treścią aktu może nastąpić bez potrzeby badania, w jakim zakresie dana relacja filiacyjna jest zgodna z prawem polskim. Dotyczy to zatem również dwóch rodziców płci męskiej. Informacji o rodzicach nie powinno się pomijać. Ich ujawnienie, choćby w ramach adnotacji odwołującej się do zagranicznego dokumentu, jest bardzo ważne, zwłaszcza w przypadku cudzoziemców. W świetle wiążących Polskę umów międzynarodowych krajowy akt małżeństwa lub zgonu cudzoziemca może podlegać przekazaniu do innego państwa ${ }^{53}$. Dane dotyczące rodziców powinny być zatem podane, aby w państwie pochodzenia nie pojawiły się wątpliwości co do tego, o jaką osobę chodzi.

Wracając jednak do głównego wątku, w ramach podsumowania ostatniej części rozważań należy stwierdzić, że w przypadku transkrybowanych do polskiego rejestru aktów urodzenia dzieci par jednopłciowych możliwość ich unieważnienia przed sądem wystąpi, zdaniem autora, zupełnie wyjątkowo i tylko wtedy, gdy w akcie urodzenia nie wpisano matki, która urodziła dziecko. W praktyce chodzi o akty urodzenia dzieci, których rodzicami, zgodnie z prawem obcym, są dwaj mężczyźni, lub gdy wiadomo, że doszło do adopcji przez parę homoseksualną, albo gdy dziecko urodziła matka zastępcza ${ }^{54}$. W takich przypadkach można twierdzić, że polski akt, niezależnie od sposobu ujawnienia rodzicielstwa, nie ma wystarczającej mocy dowodowej w zakresie pochodzenia dziecka. Zgodnie z art. $39 \S 1$ p.a.s.c., unieważnienia aktu może się domagać prokurator, kierownik USC, a także osoba zainteresowana, która wykaże swój interes prawny. Jednocześnie trzeba jednak zastrzec, że unieważnienie sporządzonego aktu z pewnością nie powinno być orzekane automatycznie. Nawet jeśli pojawiają się określone zastrzeżenia co do mocy dowodowej dokumentu, sąd powinien każdorazowo bardzo wnikliwie zbadać oko-

${ }_{52}$ Zob. M. Wojewoda, Zagraniczne rodzicielstwo..., s. 37.

${ }_{53}$ Zob. w szczególności art. 1 Konwencji nr 3 dotyczącej międzynarodowej wymiany informacji z zakresu stanu cywilnego z 4 września 1958 r. (Dz.U. 2003, nr 172, poz. 1667). Obowiązek taki przewidują także niektóre umowy dwustronne podpisane przez Polskę.

${ }^{54} \mathrm{~W}$ tym przypadku sytuacja jest szczególnie kłopotliwa, bo akt stanu cywilnego często nie ujawnia faktu surogacji, zob. M. Wojewoda, Macierzyństwo zastępcze..., s. 513. Jeśli jednak wiadomo, że dziecko urodziła matka zastępcza, to nie powinno dojść do transkrypcji, zob. wyr. NSA z 10.09.2020, II OSK 1390/18. 
liczności sprawy. W szczególności, w danym stanie faktycznym, przeciwko unieważnieniu aktu może przemawiać zasada dobra dziecka ${ }^{55}$. Jest to zasada konstytucyjna (zob. art. 72 ust. 1 Konstytucji RP ${ }^{56}$ ), która znajduje silne oparcie $\mathrm{w}$ prawie międzynarodowym (zob. art. 3 ust. 1 Konwencji o prawach dziecka z 1989 r. ${ }^{57}$ ). Warto też odnotować, że Europejski Trybunał Praw Człowieka orzekający w sprawach dotyczących dzieci urodzonych w procedurach surogacyjnych wielokrotnie zaznaczał, że odmowa zarejestrowania ich aktów urodzenia w innym państwie może stanowić niekiedy naruszenie obowiązku poszanowania życia prywatnego dziecka ${ }^{58}$ (art. 8 Europejskiej konwencji praw człowieka ${ }^{59}$ ). Możliwość powoływania się na zasadę dobra dziecka jako negatywną przesłankę unieważnienia aktu stanu cywilnego wymaga jednak z pewnością dokładnego rozważenia i zasługuje na osobne opracowanie.

Dostrzegając ograniczone możliwości podważenia aktu stanu cywilnego, który trafił już do polskiego rejestru, a także przyjmując, że w odniesieniu do aktów urodzenia dzieci par jednopłciowych tryb unieważnienia może być zastosowany tylko wyjątkowo, należy się jeszcze zastanowić, czy możliwe jest zaskarżenie czynności materialno-technicznej kierownika USC, który dokonał transkrypcji.

\section{Materialno-techniczna czynność transkrypeji i jej zaskarżenie}

Przepisanie zagranicznego aktu stanu cywilnego do polskiego rejestru dokonuje się w drodze czynności materialno-technicznej (art. 105 ust. 1 p.a.s.c.). Nasuwa się pytanie, czy sama ta czynność mogłaby zostać zaskarżona w trybie administracyjnym, który służy kontroli wyda-

${ }_{55}$ Por. M. Wojewoda, Surrogate motherhood and the civil status registration in Poland, in: Fundamental legal problems of surrogate motherhood. Global perspective, ed. P. Mostowik, Wydawnictwo Instytutu Wymiaru Sprawiedliwości, Warszawa, 2019, s. 846 i n., gdzie autor rozważa kwestię możliwości unieważnienia transkrybowanego w Polsce aktu stanu cywilnego dotyczącego dziecka urodzonego za granicą przez inną kobietę niż ta, którą wskazano w zagranicznym akcie jako matka.

${ }^{56}$ Dz.U. 1997, nr 78, poz. 483.

${ }^{57}$ Dz.U. 1991, nr 120, poz. 526.

${ }_{58}$ Zob. M. Wojewoda, Macierzyństwo zastępcze..., s. 511-513; na znaczenie orzecznictwa ETPCz zwraca tė̇ uwagę M. Zachariasiewicz, Transkrypcja..., s. 161-164.

${ }^{59}$ Konwencja o ochronie praw człowieka i podstawowych wolności, sporządzona w Rzymie 4 listopada 1950 r., zmieniona następnie odpowiednimi protokołami, Dz.U. 1993, nr 61, poz. 284. 
wanych przez kierownika USC decyzji administracyjnych. Choć orzecznictwo zdaje się dopuszczać taką możliwość, zdaniem autora niniejszego opracowania, praktyka ta nie jest prawidłowa.

Problem z całą ostrością ujawnił się w sprawie, której dotyczył wyrok NSA z 10.10.2018 r. (II OSK 2552/16), zezwalający na transkrypcję aktu urodzenia wskazującego na rodzicielstwo dwóch kobiet. Na podstawie powołanego orzeczenia kierownik USC w Krakowie sporządził polski akt urodzenia dziecka. Następnie jednak prokurator zaskarżył czynność kierownika USC do sądu administracyjnego, domagając się „uchylenia aktu urodzenia". Wyrokiem z 4.06.2019 r. Wojewódzki Sąd Administracyjny w Krakowie skargę oddalił ${ }^{60}$, zauważając, że zmierzała ona do podważenia prawomocnego wyroku NSA, pozwalającego na dokonanie transkrypcji. Skład orzekający zaznaczył dodatkowo, że podziela pogląd o możliwości umiejscowienia zagranicznego aktu urodzenia dziecka pary jednopłciowej (orzeczenie zapadło przed wydaniem uchwały 7 sędziów NSA z 2.12.2019 r.). Zaskakujące jest jednak, że sama dopuszczalność zaskarżenia materialno-technicznej czynności przepisania aktu nie była przez sąd analizowana ani w jakikolwiek sposób uzasadniona ${ }^{61}$. Tymczasem wydaje się, że skargę prokuratora należało odrzucić na podstawie art. $58 § 1$ pkt 1 p.p.s.a., ze względu na to, że sprawa nie należy do właściwości sądu administracyjnego. Jak już bowiem powiedziano, okoliczność, że akt stanu cywilnego znalazł się w rejestrze powoduje, że jego usunięcie $\mathrm{z}$ obiegu prawnego wymaga skorzystania $\mathrm{z}$ jednej ze specjalnie przewidzianych w tym celu procedur. Nie należy do nich sądowe postępowanie administracyjne wywołane skargą na czynność materialno-techniczną transkrypcji aktu stanu cywilnego. W grę wchodził co najwyżej wniosek do sądu cywilnego o unieważnienie aktu, złożony na podstawie art. 39 p.a.s.c., przy czym w świetle dotychczasowych uwag można z góry powiedzieć, że żądanie takie nie zasługiwałoby na uwzględnienie.

Warto odnotować, że Prawo o aktach stanu cywilnego z 2014 r. zna stosunkowo liczne przypadki, w których określona czynność kierownika USC nie może być kwestionowana w trybie administracyjnym, ale podlega kontroli w postępowaniu przed sądem powszechnym. Chodzi tu m.in. o sytuacje, gdy następuje odmowa dokonania jednej z czynności wymienionych $\mathrm{w}$ art. 89 p.a.s.c. ${ }^{62}$, albo gdy kierownik USC odma-

${ }^{60}$ Sygn. akt III SA/Kr 233/19.

${ }^{61}$ Lektura uzasadnienia wyroku pozwala stwierdzić, że z niezrozumiałych względów uwaga sądu koncentrowała się na ustaleniu interesu prawnego dziecka, postrzeganego jako przesłanka uprawnienia do złożenia skargi. Jest to o tyle zaskakujące, że skarga została wniesiona przez prokuratora, a nie przez małoletniego.

${ }^{62}$ Chodzi o odmowę: przyjęcia oświadczeń o wstąpieniu w związek małżeński, wydania zaświadczenia do ślubu „konkordatowego” lub do ślubu za granicą, zezwolenia na 
wia przyjęcia oświadczeń o uznaniu dziecka (art. 64 p.a.s.c.), lub gdy odmawia dokonania czynności na podstawie zagranicznego orzeczenia, kwestionując możliwość jego uznania w Polsce (art. 108 p.a.s.c. w zw. z art. 1146 k.p.c.). Są to szczególne przypadki tzw. postępowań hybrydowych, w których działanie organu administracji (kierownika USC) nie jest kontrolowane przez organ wyższego stopnia, a następnie przez sąd administracyjny, ale stanowi sprawę cywilną podlegającą rozpatrzeniu przez sąd powszechny ${ }^{63}$. Należy przyjąć, że także w przypadku sporządzenia aktu stanu cywilnego (zarówno w pierwotnym trybie rejestracyjnym, jak i przy transkrypcji) sama czynność kierownika USC nie może być zaskarżona w trybie administracyjnym. Kwestionowany może być jedynie wynik tej czynności, czyli krajowy akt stanu cywilnego. Jego podważenie może się przy tym dokonać - jak wcześniej wyjaśniono - tylko w ramach jednej ze ściśle określonych procedur. Gdyby dopuszczalny był tu tryb administracyjny, to pod znakiem zapytania stałyby takie regulacje, jak chociażby art. 2 k.r.o. przewidujący powództwo o nieistnienie małżeństwa czy sygnalizowane wcześniej unormowania dotyczące unieważnienia aktu stanu cywilnego przez sąd (art. 39 p.a.s.c.) albo przez wojewodę, lub kierownika USC (art. 39a-39b p.a.s.c., art. 127 p.a.s.c.). Tymczasem istnienie powołanych przepisów stanowi wyraźną wskazówkę, że kontrola działania kierownika USC sporządzającego akt stanu cywilnego może się dokonać wyłącznie $\mathrm{w}$ ramach ściśle określonych procedur, z wyłączeniem ogólnego trybu administracyjnego. Innymi słowy, skoro wynikiem umiejscowienia jest akt stanu cywilnego, zamknięta jest droga zmierzająca do zaskarżenia samej czynności transkrypcji. Jeżeli mimo to zostanie wniesiona skarga, to zachodzi podstawa do jej odrzucenia, bo sprawa nie należy do właściwości sądu administracyjnego (art. $58 \S 1$ pkt 1 p.p.s.a.).

Jak już jednak powiedziano, w orzecznictwie administracyjnym znane są przypadki uznania dopuszczalności zaskarżenia czynności kierownika USC, który dokonał transkrypcji. Oprócz cytowanego wcześniej orzeczenia WSA w Krakowie z 4.06.2019 r. (III SA/Kr 233/19), kolejnym przykładem jest wyrok Wojewódzkiego Sądu Administracyjnego w Szczecinie z 19.03.2020 r. (II SA/Sz 1075/19). Sąd rozpoznał skarge na umiejscowienie holenderskiego aktu urodzenia dziecka pary jednopłciowej (dwóch kobiet) i stwierdził bezskuteczność zaskarżonej czyn-

zawarcie małżeństwa przed upływem ustawowego terminu liczonego od złożenia przez nupturientów zapewnienia o braku przeszkód małżeńskich, a także sporządzenia aktu małżeństwa po jego zawarciu przed duchownym.

${ }^{63}$ Zob. J. Mrożek, O wtaściwościach postępowania hybrydowego w regulacji ochrony konkurencji $i$ konsumenta, „Acta Universitatis Wratislaviensis” 2017, no. 3798, s. $291-293$. 
ności materialno-technicznej. Ciekawie jednak przedstawiają się dalsze losy sprawy. Jak była już o tym mowa, samo orzeczenie sądu administracyjnego nie stanowi podstawy do wyeliminowania $\mathrm{z}$ obrotu aktu stanu cywilnego sporządzonego w rejestrze. Dlatego też, w związku z zapadłym wyrokiem WSA, kierownik USC skierował do sądu powszechnego wniosek o unieważnienie aktu, powołując się na art. 39 p.a.s.c. Sąd Rejonowy w Świnoujściu oddalił wniosek ${ }^{64}$, trafnie przyjmując, że nie są spełnione przesłanki wskazane w przepisie. Po pierwsze bowiem, nie było kwestionowane urodzenie dziecka, a po wtóre, nie stwierdzono wystarczających uchybień w zakresie mocy dowodowej aktu, w którym jako matkę prawidłowo wskazano kobietę, która dziecko urodziła ${ }^{65}$.

Należy zatem stwierdzić, że niezależnie od tego, czy uznamy, że dopuszczalne jest zaskarżenie czynności transkrypcji, czy też nie, kwestia ta nie ma bezpośredniego znaczenia dla dalszych losów aktu stanu cywilnego, który został już sporządzony w polskim rejestrze. Sądowe potwierdzenie wadliwości działań kierownika USC samo w sobie nie stanowi bowiem przesłanki unieważnienia aktu. Nawet jeżeli, jak przyjęto w uchwale 7 sędziów NSA, w podobnej sytuacji nie powinno dojść do transkrypcji, to w przypadku, gdy polski akt urodzenia już powstał, zwykle brak jest podstaw do jego podważenia. Powinien on pozostać w obiegu prawnym.

Jednak biorąc pod uwagę różne metody, jakie stosowano w celu określenia rodziców przy przepisywaniu do polskiego rejestru aktów urodzenia dzieci par jednopłciowych, należy się jeszcze zastanowić, czy sporządzony akt nie powinien $\mathrm{w}$ określonych przypadkach podlegać sprostowaniu.

${ }^{64}$ Nieprawomocne postanowienie z 11.09.2020, sygn. akt I Ns 199/20 [niepubl.].

${ }_{65} \mathrm{Na}$ poparcie tezy, zgodnie z którą ewentualna wadliwość czynności kierownika USC nie wpływa bezpośrednio na losy aktu sporządzonego w trybie transkrypcji, warto też przywołać post. SR dla Łodzi-Śródmieścia w Łodzi z 29.05.2018, I Ns 1634/15 [niepubl.]. Sprawa dotyczyła sytuacji, w której organ wyższego stopnia stwierdził nieważność decyzji administracyjnej kierownika USC, na mocy której dokonano transkrypcji zagranicznego aktu zgonu (w poprzednim stanie prawnym, pod rządami którego działał kierownik USC, przyjmowano, że transkrypcja wymaga wydania decyzji). Wobec stwierdzenia nieważności decyzji (co nastąpiło z powodów proceduralnych) kierownik USC wystąpił o unieważnienie sporządzonego przez siebie aktu zgonu. Sąd cywilny nie znalazł jednak podstaw do uwzględnienia wniosku, co było następstwem ustaleń, że akt stwierdzał zdarzenie zgodne z prawdą i miał prawidłową treść. 


\section{Sprostowanie polskiego aktu stanu cywilnego, który nie ujawnia drugiego rodzica tej samej płei}

Jak już wcześniej zasygnalizowano w niniejszym opracowaniu, w przypadku aktów urodzenia dzieci par jednopłciowych, które zostały przepisane po liberalnym orzeczeniu NSA z 10.10 .2018 r., w urzędach stanu cywilnego stosowano różne rozwiązania co do wypełnienia w polskim akcie rubryk poświęconych rodzicom. Zdaniem autora, w przypadku, gdy obcy dokument źródłowy wskazuje na rodzicielstwo dwóch kobiet, najbardziej właściwe wydaje się wpisanie w rubryce „matka” danych kobiety, która dziecko urodziła, i pozostawienie pustej rubryki dotyczącej ojca. Jednocześnie w treści adnotacji o sporządzeniu aktu w trybie transkrypcji (zamieszczanej obligatoryjnie na podstawie art. 105 ust. 1 in fine p.a.s.c.) powinna się znaleźć dodatkowa informacja, że zgodnie $\mathrm{z}$ prawem obcym dziecko ma drugiego rodzica, i że jest nim osoba tej samej płci co kobieta wpisana w rubryce „matka”. Taki techniczny sposób ujawnienia drugiego rodzica pozwala pogodzić założenia wynikające $\mathrm{z}$ polskiego prawa rodzinnego z zasadą wiernego przepisania aktu i dążeniem do możliwie pełnego ukazania stanu cywilnego danej osoby. Przywołane rozwiązanie jest zgodne ze wskazówkami, jakie po orzeczeniu NSA z 10.10.2018 r. przedstawiło Ministerstwo Spraw Wewnętrznych i Administracji ${ }^{6}$.

Część aktów była jednak przepisywana w inny sposób. Dość często dochodziło do całkowitego pominięcia informacji o drugim rodzicu tej samej płci. Co więcej, znane są przypadki, w których rubrykę poświęconą ojcu wypełniano tzw. danymi kryjącymi z przywołaniem art. 61 ust. 2 p.a.s.c. Przepis ten stanowi, że „Jeżeli nie nastąpiło uznanie ojcostwa albo sądowe ustalenie ojcostwa, w akcie urodzenia zamieszcza się jako imię ojca imię wskazane przez osobę zgłaszającą urodzenie, a w razie braku takiego wskazania $\mathrm{w}$ akcie urodzenia zamieszcza się jako imię ojca imię wybrane przez kierownika urzędu stanu cywilnego; jako nazwisko ojca i jego nazwisko rodowe zamieszcza się nazwisko matki z chwili urodzenia dziecka, z adnotacją o wpisaniu nazwiska matki i wybranego imienia jako danych ojca". Taki sposób transkrypcji, z wykorzystaniem danych kryjących, daje jednak podstawę do postawienia zarzutu naruszenia zasady dokładnego przepisania aktu. Zgodnie z art. 104 ust. 2 p.a.s.c., „transkrypcja polega na wiernym i literalnym przeniesie-

${ }^{66}$ Zob. pismo Małopolskiego Urzędu Wojewódzkiego w Krakowie z 5.04.2019 r. do Biura Rzecznika Praw Obywatelskich (WO-I.6234.13.2019), powołujące korespondencje z MSWiA w sprawie dotyczącej sporządzenia aktu urodzenia dziecka pary jednopłciowej. 
niu treści zagranicznego dokumentu stanu cywilnego zarówno językowo, jak i formalnie, bez żadnej ingerencji w pisownię imion i nazwisk osób wskazanych w zagranicznym dokumencie stanu cywilnego". Jak się przyjmuje, kierownik USC „nie może dokonać żadnej merytorycznej, a także formalnej ingerencji w treść polskiego aktu, czyniąc go niezgodnym z treścią przedstawionego do transkrypcji aktu zagranicznego"67.

W wyniku naruszenia powołanej zasady, polegającego na wpisaniu do krajowego aktu danych kryjących, których nie było w akcie źródłowym, dochodzi do niebezpiecznej sytuacji. W obrocie prawnym funkcjonują dwa akty stanu cywilnego - zagraniczny oraz polski - dotyczące tego samego zdarzenia, ale różniące się treścią w odniesieniu do filiacji. Pamiętając zaś, że zagraniczne akty stanu cywilnego są dokumentami urzędowymi w rozumieniu art. 1138 k.p.c. i stanowią wyłączny dowód zdarzeń w nim stwierdzonych (art. 3 p.a.s.c.) ${ }^{68}$, łatwo dostrzec, że opisywany tu sposób transkrypcji powoduje, że istnieją dwa częściowo sprzeczne dowody wyłączne dotyczące pochodzenia dziecka. Sytuacja taka jest wysoce niepożądana. Właściwą drogą do jej usunięcia wydaje się sprostowanie polskiego aktu stanu cywilnego. Przypomnijmy bowiem, że zgodnie z cytowanym wyżej postanowieniem Sądu Najwyższego z 26.03.1992 r. (I CRN 20/92), niektóre błędy w zakresie określenia pochodzenia dziecka mogą być usuwane w drodze sprostowania ${ }^{69}$.

W tych zatem przypadkach, w których doszło do pominięcia danych drugiego rodzica tej samej płci z jednoczesnym wpisaniem $\mathrm{w}$ akcie urodzenia danych kryjących w rubryce „ojciec”, należy rozważyć sprostowanie aktu, które będzie obejmowało dwa następujące elementy:

- wykreślenie danych kryjących (czemu powinno towarzyszyć wykreślenie adnotacji, że dane umieszczono na podstawie art. 61 ust. 2 p.a.s.c.);

- ujawnienie danych drugiego rodzica $\mathrm{w}$ treści adnotacji informującej o transkrypcji; zasadne wydaje się podanie w adnotacji wyjaśnienia, że danych tych nie wpisano w rubryce „ojciec”, gdyż drugi rodzic, zgodnie z dokumentem zagranicznym, jest kobietą.

Każdy z zasugerowanych elementów sprostowania wymaga szerszego komentarza. Gdy chodzi o dane kryjące, to - jak już zaznaczono ich umieszczenie $\mathrm{w}$ akcie urodzenia dokonuje się na podstawie art. 61 ust. 2 p.a.s.c. Komentując tę regulację w kontekście transkrypcji, warto rozpocząć od pytania o jej ratio legis. Korzenie powołanej konstrukcji sięgają połowy XX w. (zob. art. 62 ust. 2 dekretu - Prawo o aktach sta-

67 Tak WSA w Szczecinie w wyr. z 19.03.2020, II SA/Sz 1075/19.

68 Zob. uchwałę 7 sędziów Sądu Najwyższego z 20.11.2012, III CZP 58/12.

${ }^{69}$ Pogląd ten jest też od dawna akceptowany w literaturze, zob. K. Gondorek, A. Ustowska, Prawo o aktach..., s. 49 oraz s. 142. 
nu cywilnego z $1945 \mathrm{r}^{70}$ po nowelizacji z $1950 \mathrm{r}$. $^{71}$, a także art. 34 ust. 2 dekretu - Prawo o aktach stanu cywilnego z $1955 \mathrm{r.}^{72}$ ). Ustawodawcy chodziło o ukrycie pozamałżeńskiego pochodzenia dziecka ${ }^{73}$. Trzeba jednak powiedzieć, że w realiach obyczajowych trzeciej dekady XXI w. okoliczność, że dziecko nie urodziło się w małżeństwie nie stanowi już elementu stygmatyzującego. Współcześnie wpisywanie danych kryjących tworzy jedynie mylny obraz stosunków filiacyjnych. Dlatego też de lege ferenda postuluje się usunięcie wspomnianej konstrukcji z prawa polskiego $^{74}$. Co zaś istotne z punktu widzenia niniejszego opracowania, również de lege lata istnieją przypadki, w których wpisywanie danych kryjących nie powinno mieć miejsca. W literaturze zauważa się, że art. 61 ust. 2 p.a.s.c. może znaleźć zastosowanie wyłącznie wtedy, gdy kierownik USC dokonuje pierwotnej rejestracji urodzenia w Polsce. Natomiast w przypadkach, w których akt urodzenia powstaje w trybie transkrypcji, brak jest podstaw do stosowania tego przepisu ${ }^{75}$. Transkrypcja ma charakter reprodukcyjny, a jej zadaniem jest ścisłe odwzorowanie treści aktu sporządzonego w innym państwie. Dlatego też krajowa reguła, zakładająca obowiązek wpisania do rubryki „ojciec” fikcyjnych danych, musi ustąpić pierwszeństwa zasadzie wiernego przepisania zagranicznego aktu (art. 104 ust. 2 p.a.s.c.) ${ }^{76}$.

W przypadku dzieci, których rodzice zgodnie z prawem obcym są tej samej płci, umieszczanie w ich polskim akcie urodzenia danych kryjących dotyczących ojca, przy jednoczesnym braku wskazania drugiego rodzica, tworzy „podwójnie fałszywy” obraz stosunków filiacyjnych. Jeśli analizujemy odpis skrócony polskiego aktu urodzenia, w którym nie przytacza się adnotacji o wpisaniu danych kryjących, a który posiada wypełnione rubryki dotyczące obojga rodziców, to możemy odnieść wra-

70 Dz.U. 1945, nr 48, poz. 272.

71 Nowelizację wprowadzono ustawą z 28.10.1950 r. o zmianie niektórych przepisów prawa o aktach stanu cywilnego, Dz.U. 1950, nr 51, poz. 468.

72 Dz.U. 1955, nr 25, poz. 151.

73 Por. J. Litwin, Prawo o aktach stanu cywilnego. Komentarz, Wydawnictwo Prawnicze, Warszawa, 1961, s. 352 i n.

${ }_{74}$ Zob. A. Kordys, Analiza zasadności nowelizacji ustawy - Prawo o aktach stanu cywilnego w nawiazaniu do art. 61 pkt 2 tej ustawy, „Metryka” 2018, nr 2, s. 101 i n., por. J. Pawliczak, Dane przestaniajace..., s. 54-56.

75 Tak J. Pawliczak, Dane przestaniajace..., s. 49-50.

76 W powoływanym już wyr. WSA w Szczecinie z 19.03.2020, II SA/Sz 1075/19, sąd, który stwierdził bezskuteczność czynności kierownika USC, obiter dictum uznał za nieprawidłowe wprowadzenie danych kryjących w polskim akcie urodzenia dziecka. Jak czytamy w uzasadnieniu, kierownik USC nie był uprawniony, by zastosować art. 61 ust. 2 p.a.s.c., gdyż działał w trybie transkrypcji (która wymaga wiernego przepisania aktu), a ponadto był związany treścią wniosku, w ramach którego domagano się ujawnienia wszystkich danych w zgodzie z holenderskim aktem urodzenia. 
żenie, że dziecko posiada matkę i ojca. Jeśli zaś czytamy odpis zupełny (zawierający adnotację o zastosowaniu art. 61 ust. 2 p.a.s.c.), to dochodzimy do wniosku, że dziecko ma tylko matkę i nie posiada drugiego rodzica. Tymczasem oba wnioski są nieścisłe, gdyż w rzeczywistości - przynajmniej w świetle prawa obcego - dziecko nie posiada ojca, ale ma dwoje rodziców. Aby oddać rzeczywisty stan relacji filiacyjnych (w szerokim międzynarodowym ujęciu), w treści istniejącej adnotacji o transkrypcji należy ujawnić także dane drugiego rodzica. W tym celu adnotacja winna być sprostowana.

Gdy chodzi o wspomniany drugi aspekt sprostowania i możliwość poprawienia w tym trybie adnotacji (a nie tylko głównej treści aktu), wypada zauważyć, że skoro adnotacja jest częścią aktu stanu cywilnego, to podlega korekcie jak każdy inny element aktu ${ }^{77}$. Zgodnie z art. 23 p.a.s.c., adnotacja zawiera „informacje o okolicznościach i podstawie rejestracji urodzenia, małżeństwa albo zgonu”. Adnotacja powinna zatem informować nie tylko o sporządzeniu aktu w szczególnym trybie umiejscowienia, czego wprost wymaga art. 105 ust. 1 p.a.s.c., lecz także o innych okolicznościach, które okazują się istotne przy różnych niestandardowych przypadkach transkrypcji. W rozważanych tu przypadkach adnotacja może obejmować informacje o osobie drugiego rodzica dziecka, który nie podlega ujawnieniu w głównej części aktu.

Wypada powtórzyć, że zasada wiernego dokonania transkrypcji powinna być realizowana w sposób elastyczny, uwzględniający odmienności rejestracyjne i różnice w przepisach merytorycznych, jakie obowiązują w Polsce i w państwie pochodzenia dokumentu źródłowego. Chroniąc integralność własnego systemu rejestracji stanu cywilnego, należy zastosować różne istniejące mechanizmy w celu oddania treści zagranicznego aktu w możliwie pełnym zakresie. Tylko w ten sposób można zrealizować podstawową funkcję aktów stanu cywilnego, jaką jest wszechstronne i wiarygodne informowanie o stanie cywilnym osoby fizycznej. W dobie intensyfikacji obrotu międzynarodowego krajowy system rejestracji nie może być zamknięty na zmiany stanu cywilnego dokonywane za granicą. O tym, że polski ustawodawca nie zamierzał izolować naszego rejestru stanu cywilnego, najlepiej przekonuje sama instytucja transkrypcji. Znamienne jest, że obowiązująca regulacja pozwala na umiejscowienie w Polsce nawet takich aktów stanu cywilnego, które nie wykazują żadnego obiektywnego związku z naszym krajem.

Jednocześnie należy silnie zaakcentować, że dokonanie w treści polskiego aktu sugerowanej tu adnotacji o drugim rodzicu tej samej płci

${ }^{77}$ Kwestia ta nie budziła wątpliwości już w dawnym prawie, zob. J. Litwin, Prawo..., s. 259. 
nie oznacza automatycznego uznania w Polsce relacji filiacyjnej łączącej dziecko z kobietą będącą drugą matką. Wpis taki nie ma charakteru konstytutywnego, a jedynie czysto informacyjny. Stanowi sygnał, że w opinii państwa, w którym sporządzono akt urodzenia, dziecko posiada dwoje rodziców jednej płci. Natomiast z perspektywy prawa polskiego za przesądzone można uznać wyłącznie macierzyństwo kobiety, która dziecko urodziła (por. art. $61^{9}$ k.r.o.). Brak wiążących ustaleń co do drugiego rodzica uwidacznia pozostawiona pusta rubryka dotycząca ojca.

\section{Procedura sprostowania polskiego aktu urodzenia}

Przyjmując, że w przypadku niektórych aktów urodzenia dzieci par jednopłciowych, które zostały przepisane do polskiego rejestru, może być potrzebne ich sprostowanie, należy rozważyć, w jakim dokładnie powinno to nastąpić trybie. Podobnie bowiem jak w przypadku unieważnienia aktu stanu cywilnego, także jego sprostowanie może się dokonać w procedurze administracyjnej lub przed sądem cywilnym.

Zgodnie z art. 35 ust. 1 p.a.s.c., ,akt stanu cywilnego, który zawiera dane niezgodne $\mathrm{z}$ danymi zawartymi w aktach zbiorowych rejestracji stanu cywilnego lub z innymi aktami stanu cywilnego, o ile stwierdzają one zdarzenie wcześniejsze i dotyczą tej samej osoby lub jej wstępnych, albo z zagranicznymi dokumentami stanu cywilnego, podlega sprostowaniu przez kierownika urzędu stanu cywilnego, który go sporządził”. Jeśli chodzi o dokumenty zagraniczne stanowiące podstawę sprostowania, to art. 35 ust. 2 p.a.s.c. doprecyzowuje, że musi to być dokument zawierający dane podlegające sprostowaniu, musi dotyczyć tej samej osoby lub jej wstępnych, a także musi stwierdzać zdarzenie wcześniejsze.

Z powołanych przepisów wynika, że przy sprostowaniu aktu w uproszczonym trybie (przez kierownika USC) punktem odniesienia mogą być albo akta zbiorowe rejestracji stanu cywilnego, albo też krajowe lub zagraniczne akty stanu cywilnego (niezłożone dotąd do akt zbiorowych), dotyczące zdarzeń wcześniejszych niż zdarzenie objęte kwestionowanym wpisem. Dodajmy też, że zgodnie z art. 26 p.a.s.c., akta zbiorowe rejestracji stanu cywilnego obejmują „dokumenty stanowiące podstawę sporządzenia aktu stanu cywilnego lub dokumenty złożone po sporządzeniu aktu stanu cywilnego stanowiące podstawę do dołączenia wzmianki dodatkowej do aktu stanu cywilnego lub stanowiące podstawę zamieszczenia przypisku przy innych aktach stanu cywilnego". 
Gdy zaś chodzi o sądowy tryb sprostowania, to - na zasadzie przeciwieństwa - jest on właściwy wtedy, gdy sprostowanie nie jest możliwe na podstawie dokumentów wskazanych w art. 35 p.a.s.c. lub nie jest ono możliwe wyłącznie na podstawie takich dokumentów (art. 36 p.a.s.c.). Sąd orzeka wtedy w postępowaniu nieprocesowym, działając na wniosek osoby zainteresowanej, prokuratora lub kierownika USC. Właściwość sądu określa się na ogólnych zasadach Kodeksu postępowania cywilnego. Zgodnie z art. 507 oraz art. $508 \S 1$ k.p.c., właściwy jest sąd rejonowy miejsca zamieszkania wnioskodawcy, a w braku miejsca zamieszkania - sąd miejsca jego pobytu. Z kolei wobec braku wskazanych wyżej podstaw - co ma szczególne znaczenie w przypadku dzieci stale przebywających za granicą — właściwy jest sąd dla m.st. Warszawy.

W świetle powołanych regulacji wydaje się jasne, że sprostowania aktu sporządzonego $\mathrm{w}$ polskim rejestrze powinien dokonać przede wszystkim kierownik USC. Jak już powiedziano, potrzeba sprostowania wynika z niewłaściwego umiejscowienia zagranicznego aktu urodzenia. W celu dopisania danych drugiego rodzica w adnotacji do polskiego aktu oraz, ewentualnie, w celu usunięcia danych kryjących dotyczących ojca dziecka właściwym punktem odniesienia jest ten sam akt, który został przedstawiony do transkrypcji. Dokument ten znajduje się w aktach zbiorowych rejestracji stanu cywilnego ${ }^{78}$, co przesądza o możliwości dokonania sprostowania w trybie administracyjnym. Tylko wyjątkowo, gdy potrzebna będzie ocena także innych dokumentów, niezbędny może się okazać wniosek do sądu.

\section{Podsumowanie}

Reasumując, należy stwierdzić, że stanowisko NSA przyjęte w uchwale 7 sędziów z 2.12.2019 r., zgodnie z którym zagraniczne akty urodzenia, w których ujawniono rodzicielstwo osób tej samej płci, nie powinny być przepisywane do polskiego rejestru, ma znaczenie przede wszystkim prewencyjne. Dostrzegając, że obce konstrukcje filiacyjne, obejmują-

${ }^{78} \mathrm{~W}$ aktach zbiorowych rejestracji stanu cywilnego gromadzi się co do zasady oryginały dokumentów, które nie podlegają zwrotowi. Wyjątkowo, na wniosek osoby, która przedkłada zagraniczny dokument stanu cywilnego, można wydać ten dokument, po uprzednim sporządzeniu kopii poświadczonej za zgodność z oryginałem przez kierownika USC, jeżeli wnioskodawca nie ma możliwości ponownego uzyskania tego dokumentu (art. 26 ust. 2 p.a.s.c.). 
ce w szczególności rodzicielstwo osób tej samej płci, nie są znane prawu polskiemu, a także uwzględniając moc dowodową oryginalnych (zagranicznych) aktów stanu cywilnego, NSA zakwestionował dopuszczalność oraz potrzebę transkrypcji aktów urodzenia dzieci par jednopłciowych. Powołane stanowisko judykatury nie ma jednak zastosowania $\mathrm{w}$ tych przypadkach, w których zagraniczny akt został już przepisany do polskiego rejestru (zwłaszcza jeśli miało to miejsce przed podjęciem uchwały przez 7 sędziów NSA). Przede wszystkim, jak wykazano powyżej, brak jest podstaw prawnych, aby umiejscowiony w polskim rejestrze akt urodzenia wyeliminować z obiegu prawnego tylko z tego względu, że transkrypcję takich aktów następczo uznano za niedopuszczalną.

Zupełnie wyjątkowo $\mathrm{w}$ grę może wchodzić unieważnienie aktu na podstawie art. 39 p.a.s.c., ze względu na jego braki w zakresie mocy dowodowej co do pochodzenia dziecka. Chodzi o przypadki, gdy w polskim akcie urodzenia nie można było podać danych kobiety, która dziecko urodziła, a tym samym - z perspektywy prawa polskiego - mogą istnieć wątpliwości zarówno co do macierzyństwa, jak i ojcostwa dziecka. Nawet jednak w takich sytuacjach za pozostawieniem aktu w obrocie może niekiedy przemawiać zasada dobra dziecka.

Tam, gdzie nie ma podstaw do unieważnienia, nie jest jednak wykluczone sprostowanie aktu. W celu wyeliminowania sprzeczności aktu transkrybowanego z zagranicznym dokumentem źródłowym może być potrzebne ujawnienie danych drugiego rodzica dziecka. Należy tego dokonać w ramach odpowiedniej adnotacji. Ponadto, jeżeli akt krajowy zawiera dane kryjące w rubryce „ojciec”, to niezbędne jest ich wykreślenie. Postulowany sposób korekty treści polskiego aktu urodzenia służy urzeczywistnieniu kilku niezwykle ważnych zasad ogólnych. Po pierwsze, pozwala zrealizować podstawową funkcję rejestru stanu cywilnego, która polega na możliwie pełnym, a jednocześnie deklaratywnym przedstawieniu stanu cywilnego osoby fizycznej. Dotyczy to nie tylko elementów stanu cywilnego ukształtowanych w Polsce, ale także za granicą. Nie ma przeszkód, by w akcie stanu cywilnego w odpowiedni sposób ujawnić konstrukcje nieznane prawu polskiemu ${ }^{79}$. Wpisy w rejestrze mają wyłącznie funkcję informacyjną i dowodową. Nie tworzą nowego stanu prawnego i nie prowadzą do powstania jakichkolwiek skutków prawnych. Przede wszystkim ujawnienie rodzicielstwa osób jednej płci wynikającego z zagranicznego aktu urodzenia nie oznacza potwierdzenia, że jest to stan zgodny z polskim prawem rodzinnym. Wykorzystanie adno-

${ }^{79}$ Por. M. Wojewoda, Matżeństwa jednoptciowe..., s. 144 i n., gdzie autor rozważa sposób ujawnienia w polskim rejestrze informacji o związkach partnerskich i małżeństwach osób jednej płci. 
tacji dla ujawnienia drugiego rodzica tej samej płci (zamiast wpisania go w głównej części aktu) w wystarczającym stopniu sygnalizuje, że chodzi o konstrukcję nieznaną prawu polskiemu.

Po drugie, uzgodnienie treści polskiego aktu ze źródłowym dokumentem obcym wzmacnia pewność prawa i bezpieczeństwo obrotu. Nie powinno bowiem dochodzić do sytuacji, w której występuje niezgodność dwóch dokumentów stanu cywilnego (polskiego i zagranicznego), z których każdy ma charakter dowodu wyłącznego w zakresie określenia pochodzenia dziecka (art. 3 p.a.s.c.).

Po trzecie, w przypadku aktów stanu cywilnego pochodzących z państw Unii Europejskiej możliwość posługiwania się na terytorium innego państwa członkowskiego (w tym przypadku Polski) krajowym odpowiednikiem zagranicznego aktu, ujawniającym także takie konstrukcje, które nie są znane lokalnie, ale wynikają z dokumentu urzędowego sporządzonego w państwie pochodzenia, realizuje zasadę swobody przepływu osób, stanowiącą jeden z filarów integracji europejskiej ${ }^{80}$.

Po czwarte wreszcie, utrzymanie w obrocie prawnym polskich aktów urodzenia dzieci rodziców jednopłciowych, przy odpowiednim ukształtowaniu ich treści, pozwala urzeczywistnić zasadę dobra dziecka. W analizowanych tu sprawach posiadanie przez dziecko polskiego aktu urodzenia pozostaje niewątpliwie w jego interesie. Dziecko ma najczęściej polskie obywatelstwo, a krajowy akt urodzenia jest mu potrzebny do uzyskania numeru PESEL i wyrobienia paszportu czy dowodu osobistego. Także w innych sprawach załatwianych w Polsce legitymowanie się polskim aktem stanu cywilnego jest znaczącym ułatwieniem, bo odpada potrzeba korzystania z tłumaczeń i pokonywania naturalnej nieufności uczestników obrotu do zagranicznych dokumentów. Niezwykle istotne jest jednak to, aby polski akt urodzenia nie wykazywał sprzeczności ze źródłowym aktem zagranicznym. Jak wykazano, możliwe jest ujawnienie drugiego rodzica w taki sposób, by nie naruszyć podstawowych reguł rejestracji stanu cywilnego, jakie przewiduje prawo polskie.

$\mathrm{Na}$ zakończenie wypada dodać, że w odniesieniu do problemu rejestracji określonych instytucji nieznanych prawu polskiemu do wprowadzenia pewnych reform mogą wkrótce skłonić Polskę orzeczenia międzynarodowych trybunałów. Coraz częściej zajmują się one zagadnieniami dotyczącymi rejestracji stanu cywilnego w stosunkach transgranicznych, a ich podejście można określić jako liberalne. W Europejskim Trybunale

${ }^{80}$ Podejście takie wpisuje się także w założenia, które leżały u podstaw przyjęcia rozporządzenia Parlamentu Europejskiego i Rady (UE) 2016/1191 z 6.07.2016 r. „w sprawie promowania swobodnego przepływu obywateli poprzez uproszczenie wymogów dotyczących przedkładania określonych dokumentów urzędowych w Unii Europejskiej”, Dz.U. UE z 26.07.2016, L 200, s. 1 i n. 
Praw Człowieka na rozpoznanie czeka obecnie kilkanaście spraw dotyczących sytuacji osób LGBT w Polsce. Część tych spraw wiąże się bezpośrednio z problematyką rejestracji stanu cywilnego ${ }^{81}$. Trybunał Sprawiedliwości Unii Europejskiej bezpośrednio zaś zajął się zagadnieniami transkrypcji aktów urodzenia par jednopłciowych ${ }^{82}$. Wyniki spraw zawisłych przed powołanymi trybunałami mogą mieć niebawem bezpośrednie przełożenie na praktykę przyjmowaną pod rządami prawa polskiego.

\section{Bibliografia}

Basior I., Czajkowska A., Sorbian D., Prawo o aktach stanu cywilnego z komentarzem, Wolters Kluwer, Warszawa, 2015.

Fundamental legal problems of surrogate motherhood. Global perspective, ed. P. Mostowik, Wydawnictwo Instytutu Wymiaru Sprawiedliwości, Warszawa, 2019.

Fundamentalne prawne problemy „surrogate motherhood”. Perspektywa krajowa, red. P. Mostowik, Wydawnictwo Instytutu Wymiaru Sprawiedliwości, Warszawa, 2019.

Gondorek K., Ustowska A., Prawo o aktach stanu cywilnego z komentarzem, Wydawnictwo Prawnicze, Warszawa, 1991.

Ignatowicz J., Nazar M., Prawo rodzinne, Wolters Kluwer, Warszawa, 2016.

Jędrejek G., Kodeks rodzinny i opiekuńczy. Komentarz aktualizowany, Lex/el. 2019.

Kamarad E., Zaświadczenie o stanie cywilnym a małżństwa i zwiazki partnerskie osób tej samej ptci, „Problemy Prawa Prywatnego Międzynarodowego” 2017, T. 17.

Kordys A., Analiza zasadności nowelizacji ustawy — Prawo o aktach stanu cywilnego $w$ nawiazaniu do art. 61 pkt 2 tej ustawy, „Metryka” 2018, nr 2.

Litwin J., Prawo o aktach stanu cywilnego. Komentarz, Wydawnictwo Prawnicze, Warszawa, 1961.

Mostowik P., Glosa do wyroku NSA z dnia 10 października 2018 r. (sygn. akt II OSK 2552/16), „Zeszyty Naukowe Sądownictwa Administracyjnego” 2019, z. 4 .

${ }^{81}$ Zob. https://www.prawo.pl/prawnicy-sady/wyroki-ze-strasburga-dotycza-sprawpolskich,502066.html [Dostęp: 21.09.2021 r.].

82 Zob. w szczególności sprawę bułgarską C-490/20, w której została już wydana opinia Rzecznika Generalnego, https://curia.europa.eu/juris/document/document.jsf?tex$\mathrm{t}=\&$ docid $=239902 \&$ pageIndex $=0 \&$ doclang $=P L \&$ mode $=$ req $\&$ dir $=\& o c c=$ first $\&$ part $=1 \& c i$ d=9168574\#Footnote1 [Dostęp: 21.09.2021 r.]. Na rozpoznanie czeka także analogiczna sprawa polska C-2/21. 
Mostowik P., Problematyka prawna żadań rejestracji $w$ polskich aktach stanu cywilnego zagranicznej fikcji prawnej pochodzenia dziecka od „rodziców homoseksualnych”, „Metryka” 2019, nr 2.

Mrożek J., O właściwościach postępowania hybrydowego w regulacji ochrony konkurencji $i$ konsumenta, „Acta Universitatis Wratislaviensis” 2017, no. 3798.

Pawliczak J., Dane przesłaniajace - nieustalenie ojcostwa, „Metryka” 2020, nr 1.

Pilich M., Uznanie dziecka a problematyka obywatelstwa, „Metryka” 2017, nr 1.

Podręcznik urzędnika stanu cywilnego, T. 2, Obrót prawny z zagranica $w$ zakresie rejestracji stanu cywilnego, red. P. Kasprzyk, Fundacja Instytut Naukowy im. Prof. Józefa Litwina, Lublin, 2019.

Przyśliwska-Urbanek E., Aktualne orzecznictwo sqdów administracyjnych dotyczace rejestracji pochodzenia dziecka od osób tej samej płci, w: Kolizyjne $i$ procesowe aspekty prawa rodzinnego, red. J. Gołaczyński, W. Popiołek, C.H. Beck, Warszawa, 2019.

System Prawa Prywatnego, T. 12, Prawo rodzinne i opiekuńcze, red. T. Smyczyński, C.H. Beck, Warszawa, 2011.

System Prawa Prywatnego, T. 20C, Prawo prywatne międzynarodowe, red. M. Pazdan, C.H. Beck, Warszawa, 2015.

Tadla T.J., Glosa do wyroków NSA z dnia 10 i 30 października 2018 r., II OSK 1868/16, II OSK 1869/16, II OSK 1870/16, II OSK 2552/16, „Zeszyty Naukowe Sądownictwa Administracyjnego" 2019, z. 3.

Wojewoda M., Jeszcze o uznawaniu stanu cywilnego $w$ stosunkach transgranicznych, „Metryka” 2020, nr 1.

Wojewoda M., Matżenstwa jednoptciowe $i$ zwiazki partnerskie $w$ polskim rejestrze stanu cywilnego?, „Studia Prawno-Ekonomiczne” 2017, T. 103.

Wojewoda M., Transkrypcja zagranicznego dokumentu stanu cywilnego — kilka uwag na temat ewolucji konstrukcji w prawie polskim, „Metryka” 2016, nr 2.

Wojewoda M., Współczesne modele prawa rodzinnego a rejestracja stanu cywilnego, „Metryka” 2019, nr 2.

Wojewoda M., Zagraniczne rodzicielstwo osób jednej płci a rejestracja stanu cywilnego $w$ Polsce - glosa do uchwaty NSA (7) z 2.12.2019 r., II OPS 1/19, „Europejski Przegląd Sądowy” 2020, nr 8.

Zachariasiewicz M., Transkrypcja aktów urodzenia dzieci par jednopłciowych, „Studia Prawno-Ekonomiczne” 2019, T. 111. 